Ilmenau University of Technology

Institute of Economics

Ilmenau Economics Discussion Papers, Vol. 19, No. 92

Culturally-Biased Voting in the Eurovision Song Contest: Do National Contests Differ?

Oliver Budzinski \& Julia Pannicke

December 2014

Institute of Economics

Ehrenbergstraße 29

Ernst-Abbe-Zentrum

D-98 684 Ilmenau

Phone 03677/69-4030/-4032

Fax 03677/69-4203

http://www.wirtschaft.tu-ilmenau.de

ISSN 0949-3859 


\title{
Culturally-Biased Voting in the Eurovision Song Contest: Do National Contests Differ?
}

\author{
Oliver Budzinski* \& Julia Pannicke ${ }^{\#+}$
}

\begin{abstract}
The economic literature on the Eurovision Song Contest (ESC) establishes empirical evidence for culturally-biased voting, more precisely also biases based on geographical closeness, political relations, ethnical and linguistic affinity. The Bundesvision Song Contest (BSC), a similar contest with principally the same rules but organized on the national level in Germany, offers a unique opportunity to compare international voting bias patterns to national voting bias patterns. Thus, this paper presents an innovative analysis by comparatively analyzing the ESC's historical data from 1998 to 2013 and the BSC's data from its beginning in 2005 until 2013 with the same econometric methodology. Our results show that voting biases do not only matter in international contests but also occur in similarly-organized national contests with roughly similar magnitude and quality - despite the cultural background of participants and voters being much more homogenous.
\end{abstract}

JEL-Codes: L82, Z10

Keywords: Eurovision Song Contest, Bundesvision Song Contest, culturally-biased voting, media economics, cultural economics

Professor of Economic Theory, Institute of Economics, Ilmenau University of Technology, Email: oliver.budzinski@tu-ilmenau.de.

\# M.Sc., Institute of Economics, Ilmenau University of Technology, Email: julia.pannicke@tuilmenau.de.

+ The authors like to thank Arne Feddersen, Thomas Ostertag, Dennis Rickert, Michael Stützer, and Jens Weghake as well as the participants of the $47^{\text {th }}$ Radein Research Seminar (February 2014), the $42^{\text {nd }}$ Hohenheimer Oberseminar (Ilmenau, April 2014), the $18^{\text {th }}$ International Conference on Cultural Economics (Montréal, June 2014), and the $11^{\text {th }}$ World Media Economics \& Management Conference (Rio de Janeiro, May 2014) for valuable and helpful comments to earlier versions of the paper. Furthermore, we are thankful to Ina Fredersdorf and Nadine Neute for valuable editorial assistance. 


\section{INTRODUCTION}

During the past decade, several papers have econometrically analyzed voting behavior in the Eurovision Song Contest (ESC), one of the most successful and longest-running international music competitions and television shows worldwide. Since inhabitants of the participating countries (in varying combinations of expert juries and audience voting) vote for the acts that each represent a participating country, allegations of political bloc-voting as well as cultural biases in the voting patterns frequently surfaced in the public discussion. While the most recent and arguably most sophisticated analyses empirically confirmed voting biases, they attributed the voting bias more to cultural-linguistic similarities between countries and geographical proximity than to political factors. So, it is basically the international, cross-cultural character of the song contest that is viewed to create and fuel voting biases. Our paper contributes to this discussion by taking advantage of some kind of a unique natural experiment that has been undertaken in German TV. The commercial TV broadcasting company ProSiebenSat.1 introduced a copy of the ESC on the national level in Germany in 2005, the so-called Bundesvision Song Contest (BSC). It is held annually and follows virtually the same rules as the ESC with the 16 German states replacing the European nations of the ESC. Thus, we have a contest that very closely resembles the ESC but with much more homogeneous participants in terms of cultural and linguistic traits. Consequently, the interesting research questions are (i) whether culturally-biased voting does occur in a national contest and (ii) how the biased voting patterns compare to those of the ESC. In our analysis, we find empirical evidence for the existence of voting bias in the national contest (BSC). Furthermore, a large set of independent variables display very similar influences on the voting patterns in both contests. Generally, bias favoring neighboring countries occurs less frequent in the national contest (BSC) than in the international contest (ESC) but only to a limited extent. Furthermore, the BSC-specific phenomenon of patriotic voting implies that overall geographic bias in the national contest is not necessarily smaller than in the international context.

The paper is structured as follows. Section 2 briefly reviews several earlier studies focusing on voting bias in the Eurovision Song Contest. Section 3 determines back- 
ground and rules of both the Eurovision and the Bundesvision song contest. Section 4 forms the main part, containing a description of our (panel) data model, the econometric analysis and the diverse variables that possibly affect the voting bias. Section 5 discusses the estimation results before section 6 concludes.

\section{LITERATURE REVIEW}

One of the first papers on the Eurovision Song Contest is Kressly and Konrad (1978) describing background and general information about the Eurovision Song Contest. Yair (1995) provides pioneering work with an exploratory study, analyzing voting behavior in the period 1975-1992 with multidimensional social network programming and finding a three-bloc political structure consisting of the Western, the Northern and the Mediterranean Bloc. Because his study focuses on the average number of points each participating country gives another over the time-period, Yair and Maman (1996) extend the study by using yearly voting patterns between the blocs and show hegemony of Western Bloc nations receiving the highest points. Gatherer (2004) identifies statistically significant voting partnerships ("the Viking Empire", the "Warsaw Pact", and two smaller blocs) by analyzing and simulating the period between 1975 and 2002.

Fenn et al. (2006) use a dynamic network approach to investigate collusive voting behavior in the ESC throughout the period of 1992-2003 and invalidate the assumption of a contest with random behavior. By using cluster analysis they reveal nonlinear patterns and infer the existence of informal cliques of participating countries. Because of some unexpected "voting cliques" (or the lack of it, e.g. no correlation between Cyprus and Turkey), the authors conclude that similarities in voting behavior cannot be explained exclusively by geographical proximity. Instead, further explanations such as cultural and historical closeness need to be considered. Gatherer (2006) extends this line of research by analyzing collusive voting behavior as a process of development, resulting in the emergence of large geographical blocs since the mid-90s.

Somewhat in parallel to this line of research, several authors scrutinize specific alternative explanations for voting results, such as the role of performance order (Re- 
nato and Ginsburgh 1996; Bruine de Bruin 2005) and differences in voting behavior between public voting (via televoting) and expert voting (by juries) (Glejser and Heyndels 2001; Haan et al. 2005). For the years 1956-1997, Haan et al. (2005) find that the order of appearance has a systematic influence on the final points in the Eurovision Song Contest, however, this effect is less pronounced with expert juries than with public juries. Furthermore, others deal with the mere-exposure effect (Verrier 2012), the role of news factors (Schweiger and Brosius 2003), the role of Turkish emigrants (Christensen and Christensen 2008), and the relevance of stereotypes (Georgiou 2008). ${ }^{1}$

The literature that is closest to our research is triggered by Fenn et al. (2006). Motivated by their negligence of relevant factors influencing voting bias, it significantly extends the set of variables taking into account as possible driving forces for biased (or non-biased) voting. For instance, Ginsburgh and Noury (2008) present an extensive and very detailed econometric analysis for explaining the voting behavior particularly with regard to the importance of the song's quality. The idea behind their study is to show "what may look as vote trading is in fact sincere voting based on 'quality', and linguistic and cultural proximities" (Ginsburgh and Noury 2008). Therefore, they distinguish between strategic and cultural voting. While the former describes two countries exchanging votes in the contest, the latter implies that countries' citizens prefer songs from certain countries based on linguistic and cultural closeness. Against this background, they compose a model for explaining the given numbers of points as well as certain other variables. These variables characterize linguistic differences (based on the lexicostatistical distances derived by Dyen et al. 1992), performance characteristics (such as gender of the lead singer, if the song is performed in a group, alone or in a duet, order of performance, where the contest is performed and whether a participant comes from that host country, sung language, etc.), and cultural distances based on Hofstede's (1980, 1991) cultural dimensions. For the period 1975-2003, Ginsburgh and Noury (2008) test the hypothesis of exchanging the votes in the contest and estimate it by linear as well

1 For reasons of completeness, there are also studies analyzing the ESC with special focus put on: ESC used as a lever for economic growth (Fleischer et al. 2002), the ESC as a proxy variable for explaining European trade (Kokko and Tingvall 2012) or in terms of pure simulations (Baker 2008, García and Tanase 2013). 
as non-linear methods. They show that the significance of vote trading is on the one hand only significant in some specifications of their model and on the other hand its impact is very small. However, the quality and the language of the performed song are significant and play an essential role in explaining voting behavior.

Spierdijk and Vellekoop (2009; see also Clerides and Stengos 2006) present a similar study but in contrast to the study of Ginsburgh and Noury (2008) and Haan et al. (2005), they assume that voting bias towards some songs may deviate significantly among the participants. They also introduce a range of variables to differentiate voting based on political issues from preferences based on cultural, linguistic, ethnic, and religious closeness. Their results show that a lot of countries still prefer songs of countries nearby even after correcting for linguistic and cultural aspects. Their study uncovers factors that substantially bias the votes based on cultural, linguistic, geographical, religious, and ethnical factors. However, religious and patriotic voting grew noticeably stronger since the change to the new voting system in 1997/1998 (Spierdijk and Vellekoop 2009). Although Spierdijk and Vellekoop (2009) find significance for geographical and therefore suggested political (= tactical voting) influence they do not find support for the publicly debated accusations of political voting against certain countries.

Interestingly, there is no research on the role of (culturally-bias) audience voting in national contests. Against this background, this paper aims to contribute to the existing literature by analyzing voting patterns and collusive behavior in national contests. Our study offers a unique opportunity to identify the drivers for audience voting behavior more closely by analyzing voting bias of the Bundesvision Song Contest (BSC), a similar contest organized on the national level in Germany, as well and compare it to the ESC.

\section{The Contests: BACKGROUND AND RULES}

\subsection{EUROVISION SONG CONTEST (ESC)}

The ESC is one of the longest-running and favorite annual music competitions and television shows worldwide. In 1955, the director of the European Broadcasting 
Union (EBU), Marcel Bezençon, came up with the idea of an international song contest broadcasted on television. The EBU was founded by 23 broadcasting establishments from Europe and the Mediterranean at a conference in United Kingdom in 1950 with the purpose to build a network to exchange news films. Nowadays, it is the world's leading union of public service media organizations consisting of 56 Members of states both within Europe and beyond its borders. The EBU operates inter alia EUROVISION that is not only the producer and distributer of live news and sports but also of music and cultural contents. ${ }^{2}$ The first Grand Prix Eurovision took place in Lugano on the 24th of May, 1956, with seven nations participating and being supported by their corresponding public broadcasters. ${ }^{3}$ The main aim of the contest is to "promote high-quality original songs in the field of popular music, by encouraging competition among artists, songwriters and composers through the international comparison of their songs" (EBU/UER 2013). The ESC is broadcast throughout Europe as well as in non-participating countries like Canada, Hong Kong, New Zealand, Korea and the United States. ${ }^{4}$

All active Members of the European Broadcasting Union (EBU) are invited to take part in the ESC. Membership is not restricted to European countries, for instance, Morocco and Israel participated in the contest in the past. The major investors (Germany, France, Great Britain, Spain and Italy) and the winner of the previous contest are granted guaranteed participation in the final of the contest. The other finalist positions are awarded to the ten best participants of the semifinals. In the end, all participating countries vote, even if they are not qualified for the final. The performance order used to be chosen randomly. However, since 2013 the producers of the show determine the order of performance based on dramaturgical aspects.

In the past years, the details of the voting system and the number of participating countries were frequently modified. The current system of scoring, introduced in 1975, is based upon every country creating its own ranking of the top 10 performances. The participant who obtains the highest number of votes within a country,

\footnotetext{
See http://www3.ebu.ch/cms/en/about?jsite=c49010fa-a809-4b28-a2c8-7363e32879c5.

For comparison, there were 39 participating countries in Malmö last year.

See http://www.eurovision.tv/page/history/the-story.
} 
receives twelve points, the second place will be rewarded with ten and the third place with eight points. The performers of the seven following ranks receive decreasingly seven to one point. Nine and eleven points are not awarded. An essential modification was the introduction of a televoting system in 1997 partially and 1998 fully. From now on audience votes (via telephone calls and text messages (SMS)) also decide upon the winning country and therefore influence the final results. After some fine tuning, the final points allocation of each country is nowadays compiled half-and-half by votes of the public audience and an expert jury. The jury of experts consists of five experts in each partaking country. They have to be nationals of the country they represent as well as professionally in connection with the music industry. At the same time, they are not allowed to have a business relationship with the candidate of their own country or of any other country. Both expert juries and the audience of the participating countries are not allowed to vote for their own country. After the last performance, televoting is opened for the public audience. The winner of the contest is the country with the highest number of points.

Another important change was the introduction of two semi-finals in 2004 in order to accommodate more participants. Participating countries have to compete in a qualifying round for the purpose of reaching the contest's final. All qualified countries vote in the final, but, of course, only countries participating in the final contest receive votes. This led to an increase of the total number of contestants from 24 in 2003 to 36 in 2004. While the participants had to sing their song in their country's official national language(s) from 1966-1972 and again from 1978-1998, countries are free to choose to the present day. Groups of musicians ('bands') are not allowed to exceed the number of six people. Texts, speeches and gestures of a political nature are prohibited during the contest. ${ }^{5}$

See http://www.eurovision.de/event/regeln/Die-Regeln-des-ESC,regeln103.html for the whole chapter. 


\subsection{BUNDESVISION SONG CONTEST (BSC)}

The BSC is a German music competition based on the role-model of the ESC. ${ }^{6}$ The first BSC was held on 12 February 2005 in Oberhausen. The contest was launched by entertainer Stefan Raab, who took the Eurovision Song Contest as an inspiration. He had participated in the ESC as an artist in 2000, scoring fifth place, as well as several times as a producer. Notably, the winner of the 2010 ESC, Lena MeyerLandrut, was selected through a casting process in Raab's TV-Show "Unser Star für Oslo".

All in all, the BSC rules mirror the ESC rules very closely. All 16 states of Germany take part in the BSC. In the end, the audiences in all participating countries vote for their favorite country. As in ESC, the German state winning the contest hosts the next BSC. The winner of the contest is determined by telephone calls and SMS voting by public audience. However, in contrast to the ESC, it is also possible to vote for one's own country and there is no expert jury. The points system is the same: the participant, who obtains the highest number of votes within a country, receives twelve points, the second place will be rewarded with ten and the third place with eight points. The performers of the seven following ranks receive seven to one point. Likewise, nine and eleven points are not awarded. The language of the song is free to choose with the exception of the rule that at least $50 \%$ of the text must be sung in German. After the last performance, the lines for the public voting are opened for the audience voters via telephone and SMS. Expectedly, the winner of the contest is the country with the highest number of points. ${ }^{7}$

\subsection{Relevance of Rule Differences}

While the BSC represents an almost perfect copy of the ESC and, thus, offers a near-to-perfect opportunity for comparisons of voting pattern biases in an international versus a national context, the existing differences in the rules may not be completely irrelevant. This predominantly refers to the rule that in the ESC, voters

6 The name is a combination of the prefix "Bundes" from Bundesrepublik Deutschland (Federal Republic of Germany) and the Eurovision Song Contest.

7 See http://tvtotal. prosieben.de/tvtotal/specials/bundesvision-song-contest/. 
must not vote for their own country, whereas in the BSC, voters are allowed to vote for their own country.

This may have an influence on the results due to patriotic voting. Therefore, we control for patriotic voting by introducing a dummy variable for "home bias voting". Furthermore, in an additional version, we also re-constructed the points allocation of the BSC, excluding own-state votes. Note, however, that this correction is not perfect as we cannot know what the patriotic voters might have voted for if they were not allowed to vote for their own state. If voting for neighboring states is viewed to be an extension of patriotic voting (in terms of voting motivation), then this may lead to an underestimation of geographical voting bias in the case of the BSC. Since the additional version with the re-allocated points did not yield significantly different results from our original model, we omit its results further on.

A second important difference is the non-existence of expert juries with voting power in the BSC: while expert juries have enjoyed varying degrees of voting power (currently: 50 per cent of the votes) in the ESC, all votes in the BSC come from the audience. In the literature, it is usually believed that a higher share of audience voting increases voting biases (Haan et al. 2005). To that extent, our analysis may overestimate voting bias when comparing the BSC results to the ESC results.

We do not think that other minor differences in the rules exert any influence on our results.

\section{ECONOMETRIC ANALYSES}

\subsection{DATA AND DESCRIPTIVE StATISTICS}

In our paper, we perform a comparative empirical study, tracing and comparing voting patterns and biases in the ESC and the BSC. We use a complete historical voting data set of the ESC from 1998-2013 ${ }^{8}$ and collect the BSC voting data from its beginning in 2005-2013 ${ }^{9}$. The voting results are all published by an official committee of the host country every year, in which the contests take place. These

See http://www.eurovision.tv; http://www.kolumbus.fi/jarpen/.

9 See http://tvtotal. prosieben.de/tvtotal/specials/bundesvision-song-contest/. 
voting results show the number of points each participating country or German state awarded every partaker in the contest. We use the years 1998-2013 (inclusive) for our data analysis regarding the ESC because there are hardly any changes in rules except the semi-final introduction.

In each ESC, 23-26 countries participate in the final competition, in each BSC, (the same) 16 German states compete. For the ESC, countries that participated less than three times are not taken into consideration. In total we get 13119 observations for the ESC and 2304 observations for the BSC. We tabulated, inter alia, the points given from each country $A$ to each other country $B$ for every single year. All participating countries of the final ESC are listed in Table 1. Here you can find the number of times each country participated (Year), their total number of received votes (observations) and the mean points assigned per country over all partaking years. Azerbaijan, for example, receives the highest number of points (4.495) on average from all voting countries over a period of 6 year. 


\begin{tabular}{|c|c|c|c|}
\hline $\begin{array}{l}\text { Participating } \\
\text { Countries (Final) }\end{array}$ & Years & Obs. & Mean Points Awarded \\
\hline Albania & 6 & 235 & 1.970 \\
\hline Armenia & 6 & 237 & 3.122 \\
\hline Austria & 6 & 170 & 1.758 \\
\hline Azerbaijan & 6 & 242 & 4.495 \\
\hline Belarus & 3 & 117 & 1.803 \\
\hline Belgium & 8 & 228 & 2.548 \\
\hline Bosnia and Herze. & 13 & 447 & 2.521 \\
\hline Croatia & 11 & 332 & 2.240 \\
\hline Cyprus & 9 & 269 & 1.69 \\
\hline Denmark & 12 & 407 & 3.243 \\
\hline Estonia & 10 & 301 & 2.853 \\
\hline Finland & 9 & 311 & 1.723 \\
\hline France & 16 & 532 & 1.343 \\
\hline Georgia & 5 & 201 & 2.383 \\
\hline Germany & 16 & 532 & 2.208 \\
\hline Greece & 14 & 487 & 3.626 \\
\hline Hungary & 6 & 224 & 1.72 \\
\hline Iceland & 11 & 369 & 2.081 \\
\hline Ireland & 12 & 388 & 1.373 \\
\hline Israel & 11 & 335 & 2.259 \\
\hline Italy & 3 & 121 & 3.438 \\
\hline Latvia & 8 & 251 & 2.601 \\
\hline Lithuania & 9 & 307 & 1.38 \\
\hline Macedonia & 8 & 262 & 1.408 \\
\hline Malta & 12 & 369 & 2.495 \\
\hline Moldova & 8 & 316 & 1.974 \\
\hline Netherlands & 7 & 189 & 2.365 \\
\hline Norway & 13 & 426 & 2.969 \\
\hline Poland & 6 & 170 & 1.047 \\
\hline Portugal & 7 & 214 & 1.154 \\
\hline Romania & 14 & 488 & 2.190 \\
\hline Russia & 14 & 486 & 4.018 \\
\hline Serbia & 5 & 204 & 3.916 \\
\hline Slovenia & 7 & 199 & 1.703 \\
\hline Spain & 16 & 532 & 1.419 \\
\hline Sweden & 15 & 494 & 3.447 \\
\hline Switzerland & 6 & 187 & 1.101 \\
\hline Turkey & 14 & 452 & 3.276 \\
\hline Ukraine & 11 & 418 & 3.760 \\
\hline Ukraine & 16 & 532 & 1.5 \\
\hline
\end{tabular}

Table 1 Participating countries, years, observations and mean points awarded 
The BSC displays always the same structure. Every German state participated at least nine times. Thus, there are 144 observations per German state.

In order to get a first impression on voting biases, we look at the mean number of given points between dissimilar countries and (dis)similar federal states. According to the rules each participating country has to distribute a total of 58 points $(58=$ $12+10+8+7+6+5+4+3+2+1)$ and, under the assumption that the songs quality is equal for all countries (we will qualify this assumption in the analytical part), each country obtains expectably on average $58 /(N-1)$ points per participant with $\mathrm{N}$ participants in the ESC and 58/N in the BSC. In our sample the median contest size is 25 for the Eurovision and 16 for the BSC. Assuming the randomness of the songs quality, we assume that each country will obtain from each other $58 / 24=2.42$ points in the ESC and 58/16 = 3.625 in the BSC. With our purpose to compare, we determine the mean number of awarded points between every participating country ${ }_{A}$ and country $_{B}$. In tables 2-4 we illustrate these country pairs regarding the BSC and the ESC. Column -A to B- shows the mean number of points given from country $A$ to country B throughout all years while column -All to B-presents the mean number of points given by all other participating states or countries throughout all years (except country A). As we can see, because German states are allowed to vote for themselves, they systematically award themselves more than the 3.625 points we assumed as an average. 


\begin{tabular}{|c|c|c|c|c|}
\hline Country A & Country B & $A$ to $B$ & $\begin{array}{l}\text { All to B } \\
\text { (exc.A) }\end{array}$ & $\begin{array}{c}\text { "Overvaluation" } \\
\text { A to B }\end{array}$ \\
\hline Bavaria & Bavaria & 11.8 & 1.6 & 10.2 \\
\hline Saarland & Saarland & 11.8 & 1.6 & 10.2 \\
\hline Mecklenburg-Western & Mecklenburg-Western & 11.6 & 1.6 & 10.0 \\
\hline Pomerania & Pomerania & & & \\
\hline Rhineland-Palatinate & Rhineland-Palatinate & 10.9 & 1.0 & 9.9 \\
\hline Bremen & Bremen & 12.0 & 2.5 & 9.5 \\
\hline Saxony-Anhalt & Saxony-Anhalt & 10.3 & 2.0 & 9.3 \\
\hline Hesse & Hesse & 11.3 & 3.0 & 8.3 \\
\hline Thuringia & Thuringia & 12.0 & 3.8 & 8.2 \\
\hline Saxony & Saxony & 11.3 & 3.1 & 8.2 \\
\hline Hamburg & Hamburg & 12.0 & 3.8 & 8.2 \\
\hline Baden-Wuerttemberg & Baden-Wuerttemberg & 11.8 & 4.0 & 7.8 \\
\hline Brandenburg & Brandenburg & 10.4 & 2.9 & 7.5 \\
\hline Schleswig-Holstein & Schleswig-Holstein & 10.8 & 3.6 & 7.1 \\
\hline North Rhine-Westphalia & North Rhine-Westphalia & 10.1 & 3.7 & 6.4 \\
\hline Lower Saxony & Lower Saxony & 10.9 & 4.9 & 5.9 \\
\hline Berlin & Berlin & 11.3 & 6.6 & 4.7 \\
\hline
\end{tabular}

Table 2 Country pairs vote's for each other in the BSC (1)

\begin{tabular}{|c|c|c|c|c|c|}
\hline Country A & Country B & $A$ to $B$ & B to $A$ & $\begin{array}{l}\text { All to B } \\
\text { (exc. A) }\end{array}$ & $\begin{array}{c}\text { "Overvaluation" } \\
\text { A to B }\end{array}$ \\
\hline \multicolumn{6}{|c|}{ Country $B$ is favored by Country $A$} \\
\hline Schleswig-Holstein & Hamburg & 8.0 & 7.1 & 4.1 & 3.9 \\
\hline Lower Saxony & Bremen & 6.6 & 6.0 & 2.8 & 3.7 \\
\hline Hamburg & Schleswig-Holstein & 7.1 & 8.0 & 3.9 & 3.2 \\
\hline Brandenburg & Berlin & 9.2 & 5.2 & 6.8 & 2.5 \\
\hline Saarland & Rhineland-Palatinate & 3.8 & 2.6 & 1.5 & 2.3 \\
\hline Baden-Wuerttemberg & Rhineland-Palatinate & 3.8 & 5.9 & 1.7 & 2.1 \\
\hline Berlin & Brandenburg & 5.2 & 9.2 & 3.2 & 2.0 \\
\hline Bavaria & Rhineland-Palatinate & 3.7 & 1.3 & 1.7 & 2.0 \\
\hline Saxony & Thuringia & 5.8 & 4.1 & 4.2 & 1.6 \\
\hline Rhineland-Palatinate & Hesse & 5.0 & 1.7 & 3.5 & 1.5 \\
\hline \multicolumn{6}{|c|}{ Country $B$ is not favored by Country $A$} \\
\hline Saxony & Hamburg & 2.6 & 2.1 & 4.4 & -1.9 \\
\hline Bremen & Brandenburg & 1.6 & 1.8 & 3.5 & -1.9 \\
\hline Saxony-Anhalt & Bremen & 1.2 & 1.1 & 3.2 & -2.0 \\
\hline Rhineland-Palatinate & Thuringia & 2.4 & 0.9 & 4.4 & -2.0 \\
\hline Thüringen & Hamburg & 2.4 & 3.9 & 4.5 & -2.0 \\
\hline Hamburg & Berlin & 5.0 & 3.8 & 7.0 & -2.0 \\
\hline Bavaria & Saxony & 1.4 & 1.9 & 3.5 & -2.1 \\
\hline Saxony-Anhalt & Hamburg & 2.1 & 2.1 & 4.5 & -2.3 \\
\hline $\begin{array}{l}\text { Mecklenburg-Western } \\
\text { Pomerania }\end{array}$ & Bavaria & 0.9 & 0.9 & 3.4 & -2.5 \\
\hline Lower Saxony & Thuringia & 1.9 & 4.7 & 4.5 & -2.6 \\
\hline
\end{tabular}

Table 3 Country pairs vote's for each other in the BSC, "top 10" (2) 
While the upper part of table 3 shows the top 10 German states favor another German state, the lower part illustrates those 10, who awarded points lower than average. It is remarkable that East-German states and West-German states appear to favor each other against their political-historical backgrounds of the countries' separation into East and West.

The systematic biased voting in ESC is particularly obvious when looking at the 'friendship' between Cyprus and Greece (table 4). While each country gave 1.689 points on average ${ }^{10}$, which are 0.731 points less than the supposed average number of points $(=2.42)$, Greece gave an average of 12 points (the maximal number of points) to Cyprus throughout all the 7 years in our sample. The difference between 12 points and 1.689 shows the 'overvaluation' as a possible bias („Overvaluation“ $A$ to $B=10.311$ ). Similarly, Greece received an average of 12.00 points from Cyprus, these are 8.98 points more than the average account for all years. While the first part of table 4 shows the participating countries not favoring another country, the second part lists those who awarded more points than the average. ${ }^{11}$ Thus, in addition to the absolute comparison between country pairs, also relative comparisons have to be taken into account.

\begin{tabular}{|c|c|c|c|c|c|c|c|}
\hline CountryA & Obs & $\begin{array}{l}\text { Country } \\
\text { B: is not } \\
\text { favored } \\
\text { by Coun- } \\
\text { try A }\end{array}$ & $\begin{array}{l}\text { „Under- val- } \\
\text { uation“ } \\
\text { A to B }\end{array}$ & $\begin{array}{l}\text { Yea } \\
r\end{array}$ & $\begin{array}{l}\text { Country B: } \\
\text { is favored } \\
\text { by Country } \\
\text { A }\end{array}$ & $\begin{array}{l}\text { "Over- } \\
\text { valua- } \\
\text { tion" } \\
\text { A to B }\end{array}$ & $\begin{array}{l}\text { Yea } \\
r\end{array}$ \\
\hline Albania & 242 & Armenia & $\begin{array}{l}- \\
2.84 \\
3\end{array}$ & 6 & Greece & 6.863 & 10 \\
\hline Andorra & 146 & Turkey & -3.255 & 6 & Spain & 9.133 & 6 \\
\hline Armenia & 168 & Azerbaijan & -4.565 & 5 & Georgia & 7.143 & 5 \\
\hline Austria & 240 & Ukraine & -2.602 & 7 & $\begin{array}{l}\text { Bosnia } \\
\text { Herz. }\end{array}$ & 6.715 & 8 \\
\hline Azerbaijan & 146 & Italy & -3.172 & 3 & Turkey & 8.501 & 4 \\
\hline Belarus & 245 & Turkey & -2.561 & 8 & Russia & 6.778 & 10 \\
\hline Belgium & 362 & Ukraine & -2.410 & 11 & $\begin{array}{l}\text { Nether- } \\
\text { lands }\end{array}$ & 7.215 & 6 \\
\hline Bosnia Herz. & 305 & Denmark & -2.736 & 10 & Serbia & 7.488 & 5 \\
\hline Bulgaria & 223 & Italy & -3.513 & 3 & Greece & 5.481 & 9 \\
\hline Croatia & 382 & Armenia & -3.184 & 6 & Bosnia & 7.614 & 13 \\
\hline
\end{tabular}

10 To save space we omitted some data on the voting patterns, i.e. the average number of points awarded for all countries. Those are available from the authors upon request.

11 We note the country pairs with the most pronounced "undervaluation" and "overvaluation". 


\begin{tabular}{|c|c|c|c|c|c|c|c|}
\hline & & & & & \multirow[b]{2}{*}{13} \\
\hline Cyprus & 361 & Turkey & -2.356 & 13 & $\begin{array}{l}\text { Herz. } \\
\text { Greece }\end{array}$ & 8.980 & \\
\hline $\begin{array}{l}\text { Czech Re- } \\
\text { public }\end{array}$ & 74 & Turkey & -3.614 & 3 & Armenia & 8.081 & 3 \\
\hline Denmark & 330 & Armenia & -3.184 & 6 & Sweden & 5.998 & 13 \\
\hline Estonia & 383 & Serbia & -3.994 & 5 & Latvia & 5.745 & 8 \\
\hline Finland & 312 & Armenia & -3.013 & 6 & Estonia & 6.907 & 7 \\
\hline France & 377 & Ukraine & -3.064 & 11 & Portugal & 8.234 & 7 \\
\hline Georgia & 146 & Serbia & -2.764 & 5 & Armenia & 7.978 & 4 \\
\hline Germany & 377 & Azerbaijan & -3.771 & 6 & Turkey & 6.749 & 14 \\
\hline Greece & 332 & Sweden & -2.363 & 13 & Cyprus & 10.311 & 7 \\
\hline Hungary & 194 & $\begin{array}{l}\text { Bosnia } \\
\text { Herz. }\end{array}$ & -2.424 & 6 & Iceland & 4.172 & 5 \\
\hline Iceland & 333 & Turkey & -2.521 & 12 & Denmark & 6.467 & 11 \\
\hline Ireland & 357 & Azerbaijan & -3.599 & 6 & Lithuania & 4.937 & 8 \\
\hline Israel & 382 & Serbia & -3.380 & 5 & Romania & 3.361 & 14 \\
\hline Italy & 74 & Sweden & -5.163 & 3 & Romania & 5.029 & 3 \\
\hline Latvia & 337 & Serbia & -3.380 & 5 & Estonia & 5.133 & 8 \\
\hline Lithuania & 309 & Armenia & -2.842 & 6 & Georgia & 7.603 & 5 \\
\hline Macedonia & 313 & Armenia & -2.158 & 6 & Albania & 9.424 & 6 \\
\hline Malta & 381 & Armenia & -3.013 & 5 & Italy & 6.057 & 3 \\
\hline Moldava & 216 & Turkey & -3.325 & 7 & Azerbaijan & 4.432 & 6 \\
\hline Monaco & 72 & Russia & -3.467 & 3 & France & 4.608 & 3 \\
\hline Montenegro & 126 & Ukraine & -2.923 & 5 & Serbia & 6.980 & 3 \\
\hline Netherlands & 362 & Russia & -3.329 & 13 & Turkey & 5.360 & 13 \\
\hline Norway & 356 & Armenia & -3.184 & 6 & Iceland & 5.051 & 11 \\
\hline Poland & 287 & Turkey & -2.538 & 11 & Ukraine & 4.964 & 9 \\
\hline Portugal & 312 & Armenia & -2.779 & 5 & Spain & 6.361 & 13 \\
\hline Romania & 333 & Latvia & -2.955 & 7 & Moldava & 10.043 & 8 \\
\hline Russia & 331 & Italy & -3.513 & 3 & Armenia & 5.879 & 6 \\
\hline San Marino & 102 & Ukraine & -4.224 & 4 & Greece & 4.715 & 4 \\
\hline Serbia & 171 & Turkey & -3.241 & 5 & $\begin{array}{l}\text { Bosnia } \\
\text { Herz. }\end{array}$ & 8.125 & 6 \\
\hline $\begin{array}{l}\text { Serbia \& } \\
\text { Mont. }\end{array}$ & 70 & Turkey & -2.897 & 3 & Macedonia & 7.8070 & 3 \\
\hline Slovakia & 125 & Turkey & -3.233 & 4 & Estonia & 5.509 & 4 \\
\hline Slovenia & 362 & Armenia & -2.331 & 6 & Serbia & 7.076 & 5 \\
\hline Spain & 377 & Serbia & -2.971 & 5 & Romania & 5.701 & 14 \\
\hline Sweden & 378 & Italy & -3.513 & 3 & Finland & 5.623 & 9 \\
\hline Switzerland & 315 & Russia & -3.952 & 12 & Albania & 6.685 & 6 \\
\hline Turkey & 353 & Serbia & -3.994 & 5 & Armenia & 5.427 & 5 \\
\hline Ukraine & 263 & Serbia & -2.354 & 5 & Belarus & 6.405 & 3 \\
\hline UK & 377 & Serbia & -3.994 & 5 & Ireland & 5.735 & 12 \\
\hline
\end{tabular}

Table 4 shows all participating countries $A$ and their given points in average to country $B$, the number of observations and years, in which countries participated; country pairs with min and max average bias as in Spierdijk and Vellekoop (2009). 


\subsection{Method}

Our goal is to explain possible biased votes in the ESC and BSC through our (panel) data model. Our (panel) data set consists of three dimensions, which are year = time $(t)$, juries $=$ country $(A)$ and the performed song of another country (B). Because not every country takes part every year in the ESC, our data set is unbalanced and because every German state takes part in the BSC, this data set is balanced. As Lazarsfeld et al. (1948: 137) conclude in their study that "voting is essentially a group experience. People who work or live or play together are likely to vote for the same candidates", we assume homogenous behavior of voting across participating countries and states of Germany. We follow the outstanding idea of Spierdijk and Vellekoop (2009) and also analyze the voting behavior separately for each country instead of looking at the average influence of independent variables on the dependent variable -votes-, where the average is calculated over all voting countries. We choose this method because the aim of our study is to discuss if voting bias occurs in the BSC also and if it differs from the voting bias in the ESC. Because the participating German States in the BSC correspond to the participating countries in the ESC the country-specific by has the advantage of capturing voting patterns more precisely.

Inter alia, Clerides and Stengos (2006) define the dependent variable as the number of points awarded by country A to country B. Because it is hard to measure to measure any 'true' or 'pure' quality of a song (like with any other artistic creation), they subdivided the "perceived quality" into 'objective' and 'subjective' quality elements. While the former describes observable characteristics of a song such as gender, group/solo performance or the song's language, the latter relies on intrinsic individual preferences of the voters for a special type of song. Clerides and Stengos (2006) choose to concentrate only on the objective attributes of quality that might exert an influence to the perceived song's quality (constructed as "packaging effects"). Consequently, they consider only some of the quality elements. However, a high number of given points from one country to another country could be a response to a perceived ('subjective') high song quality. Indeed, it is always questionable and difficult to measure quality of artistic performance because 
it is simply often unobservable. However, Spierdijk and Vellekoop (2009: 410) propose a very interesting proxy for "quality" 12 of the performed song:

$$
\begin{aligned}
& \text { 'quality' }_{t B,-A}=\frac{1}{n_{t A B}} \sum_{k \neq A} s_{t K B}, \\
& \text { bias }_{t A B}=s_{t A B}-\text { 'quality }_{t B,-A},
\end{aligned}
$$

$n_{t A B} \quad=$ number of all participating countries without country $\mathrm{A}$ and country $\mathrm{B}$ in year $\mathrm{t}$

$s_{t A B} \quad=$ awarded points of country A to country B's song in year $\mathrm{t}, \mathrm{s}_{\mathrm{tAB}}=0$, if country $A$ or $B$ does not vote in year $t$

Thus, we define the bias expressed by equations (1) and (2) as our dependent variable that demonstrates the difference between the given points by country $A$ to song of country $B$ and the number of points assigned by all other countries in average of year $t$ except country $A$ ('quality ${ }^{\prime} B,-\mathrm{A}$ ). The bias leads to an overvaluation ${ }^{13}$ (positive sign) or an undervaluation (negative sign). This has the considerable advantage that we have a continuous dependent variable instead of a categorical one like the final rank or the number of points given from country $A$ to country $B$ in year $\mathrm{t}$ (Spierdijk and Vellekoop 2009). Moreover, this model has the advantage that we do not have to control for quality anymore as, for example, Ginsburgh and Noury (2008) do. Therefore, we avoid problems of endogeneity and circularity.

Accordingly, we define bias $_{t A B}$ as our dependent variable (4)

$$
\text { bias }_{A B t}=\alpha_{A}+B_{A} X_{A B t}+u_{A B t}
$$

and corresponding control variables $X_{A B t}(1 \times V)$ for each dimension $t=1, \ldots, T, A$ $=1, \ldots, \mathrm{N}, \mathrm{B}=1, \ldots, \mathrm{M}$ and $\mathrm{V}$ the number of several control variables.

Finally, the estimation equation is shown in (5) in a compressed specification:

$$
\operatorname{bias}_{A}=\alpha_{A}+b_{A} X_{B}+u_{A}
$$

12 We set the word "quality" in quotation marks since we do not want to pretend that this concept represents an indisputable operationalisation of a term as difficult as quality of artistic creations and performances. In particular, it can be highly controversial whether majority assessments and evaluations (mass-culture or popular culture) represent 'quality'. For our purposes, however, it is exactly the deviation from the mass assessment among different groups of voters that we are looking for.

13 See e.g. table 4. 
We consider $\mathrm{N}$ equations. Because we have a continuous dependent variable instead of a categorical one we estimate the equations of voting (5) by linear methods (OLS) as well as individually per country because intercepts and slopes vary with the partaking and voting countries (Spierdijk and Vellekoop 2009).

\subsection{EXPLANATORY VARIABLES}

Our selection of explanatory variables is based on scientific literature in media and cultural economics concerning the ESC (see chapter 2). Because of the extensive discussion about the influence of the geographical position (inter alia Yair 1995; Gatherer 2004) and its effect on voting behavior we collect data regarding the geographical closeness of participating countries (ESC) and states of the Federal Republic of Germany (BSC). In order to capture neighboring countries we include a dummy to show whether participating countries share a common border. In contrast to Spierdijk and Vellekoop (2009), we do not only use a dummy variable for neighboring countries, but also introduce the length of common border measured in $\mathrm{km}^{14}$. Thus, we assume the longer the common border, the more points participating countries award each other. We also collect the distance between the countries capitals in order to gauge geographical closeness. Against the background of BSC we create a dummy for a former Eastern part of Germany and a -Home Biasdummy variable if the country votes for his own German State.

We define independent variables with respect to the kind of performance. These explanatory variables characterize performance characteristics such as gender (male, female) of the artist and if the song is performed by a group, a (male-) soloist or a duo. Haan et al. (2005) find evidence that the order of appearance has a systematic influence on the final points in the Eurovision Song Contest. Therefore, we defined an order-variable reflecting the order of appearance in which acts of the performing countries are viewed by the audience and jury. Because most winning songs are performed in English, we assume that language plays a role for explaining the voting behavior. Therefore, we define dummies for the songs language

\footnotetext{
14 We obtained the length of common border and the neighbor countries from https://www.cia.gov/library/publications/the-world-factbook/geos/gm.html.
} 
marking if the song is sung in English or French. We also include a dummy if the performing country was the host of the contest in year $t$.

In order to find linguistic dependences we include a dummy variable for the countries' languages as a regressor in our voting analysis ${ }^{15}$. If country A and country B share a common official language we assume a higher bias in voting.

For the period 1968 to 1972, Hofstede conducted an extensive cross-cultural investigation for a sample of forty countries. The aim of his study is to show the fundamental differences in how people from different countries experience and interpret their world. The research project was carried out with 116.000 employees by company IBM with a comparable professional position, but from different nations. Using factor analysis of the received responses, Hofstede constructed four "dimensions" to describe each country's culture. For each dimension a country-index of each participating nation is calculated. As in Ginsburgh and Noury (2008), we use Hofstede's four cultural dimensions ${ }^{16}$ in order to gather the cultural diversity among the partaking countries. ${ }^{17}$ Thus, the explanatory variable is the distances between the countries' index for a Hofstede dimension that votes and the countries' index that receives the points. Because of cultural closeness, we assume the smaller the distance the higher the voting bias. The four dimensions of Hofstede are Individualism/Collectivism, Masculinity/Femininity, Uncertainty Avoidance and Power Distance. ${ }^{18}$ For the purpose of gathering cultural variety among the participating German states we use the empirical research model of Big Five personality traits dimensions, because there is a relationship between Hofstede's cultural dimensions and the Big Five personality traits (McCrae and Terracciano 2005). These dimensions, based on the Five Factor Model (FFM) (Costa and McCrae 1992), describe human personality traits that are defined as "dimensions of individual differences in tendencies to show consistent patterns of thoughts, feelings, and actions"

\footnotetext{
15 We have obtained the language variable from the french research center in international economics (Centre d'Etudes Prospectives et d'Informations Internationales (CEPII) and CIA World Factbook, see http://www.cepii.fr/CEPII/en/bdd_modele/bdd.asp.

16 Also Long-term versus short-term orientation and Indulgence versus Restraint (IND), they are ignored in this study because of high incompleteness.

17 We have obtained the cultural dimensions from http://geert-hofstede.com/countries.html.

18 See for more information http://geert-hofstede.com/serbia.html.
} 
(McCrae and Costa 1990: 29). The five-factor dimensions consist of Neuroticism, Extraversion, Openness to Experience, Agreeableness and Conscientiousness (McCrae and John 1992). A high value in Neuroticism refers to a high share of easily depressed and anxious individuals and a low share of extroverted personalities (which are very sociable and talkative), while Openness to Experience stands for creativity, artistic skills and unconventional human beings. The Agreeableness factor represents compassion, corporation, and trust, while Conscientiousness is characterized by planned and organized behavior (Atkinson et al. 2000). We obtained the dataset for the 16 German states from the German Socio-Economic Panel Study (SOEP) that collected regional values of the Big Five traits for each state of Germany in 2005. Research has shown that the regional differences between the Big Five dimensions influence for example entrepreneurship (Obschonka et al. 2013).

Analyses in the research field of behavioral economics find evidence that economic agents' decisions are often affected by religion (inter alia, lannacconea 1998; Kuran 1994). For this reason, we assume countries to give higher amounts of points to countries with the same religion. We create a dummy variable for religion if country $A$ and $B$ share at minimum one major religion. Regarding the ESC, we follow the procedure of Spierdijk and Vellekoop (2009) and consider a religion if the percentage of individuals belonging to a certain religion is either the highest percentage among all religions, or if it is the second largest with not less than 20 percent. We differentiate between Catholics, Orthodox, Jewish, Muslims and Protestants. ${ }^{19}$ Concerning the BSC, we differentiate between Catholics, Protestants and those who have no religious affiliations. We consider those religious denominations, if the percentage of members is not less than 40 percent. Table 5 offers a concise list of the explanatory variables and their descriptions. Because a lot of explanatory variables are time-invariant, we do not take into consideration any temporal changes.

19 We have obtained the major religion from https://www.cia.gov/library/publications/the-worldfactbook/. 


\begin{tabular}{|c|c|}
\hline Geographical as- & If countries $A$ and $B$ are neighbors $=1$ \\
\hline Neighb $_{A B}$ & $\begin{array}{l}\text { Otherwise }=0 \\
\text { length of common border in km of Countries A and B }\end{array}$ \\
\hline $\begin{array}{l}\text { Length_CB } \mathrm{B}_{\mathrm{AB}} \\
\text { Capital Dis }{ }_{\mathrm{AB}}\end{array}$ & Distance between capitals of countries A and B in km \\
\hline $\begin{array}{l}\text { only for BSC: } \\
\text { former } \mathrm{GDR}_{\mathrm{B}}\end{array}$ & $\begin{array}{l}\text { If Country B was a former Eastern part of Germany }=1 \\
\text { Otherwise }=0 \\
\text { If countries A and B are the same German States }=1\end{array}$ \\
\hline Home_Bias ${ }_{A B}$ & Otherwise $=0$ \\
\hline \multicolumn{2}{|l|}{ Language } \\
\hline $\operatorname{Lang}_{A B}$ & $\begin{array}{l}\text { If Country B and Country A share a common official or primary } \\
\text { language }=1 \\
\text { Otherwise }=0\end{array}$ \\
\hline \multicolumn{2}{|l|}{ Performance } \\
\hline Male_solo & $\begin{array}{l}\text { If Country B's song was sung by a male soloist in year } t=1 \\
\text { Otherwise }=0\end{array}$ \\
\hline Duet $_{B t}$ & $\begin{array}{l}\text { If Country B's song was sung by a female-male duet in year } t=1 \\
\text { Otherwise }=0\end{array}$ \\
\hline Group $_{\mathrm{Bt}}$ & $\begin{array}{l}\text { If Country } B^{\prime} s \text { song was sung by a group in year } t=1 \\
\text { Otherwise }=0\end{array}$ \\
\hline English $_{\mathrm{Bt}}$ & $\begin{array}{l}\text { If Country B's song was in English in year } t=1 \\
\text { Otherwise }=0\end{array}$ \\
\hline French $_{\text {Bt }}$ & If Country B's song was in French in year $t=1$, otherwise $=0$ \\
\hline Order $_{B t}$ & $\begin{array}{l}\text { Order of Country B's song of in year } t \text { (one for the first per- } \\
\text { forming song) }\end{array}$ \\
\hline Host $_{\mathrm{Bt}}$ & $\begin{array}{l}\text { If Country B was the host in year } \mathrm{t}=1 \\
\text { Otherwise }=0\end{array}$ \\
\hline \multicolumn{2}{|l|}{ Cultural } \\
\hline $\begin{array}{l}\text { only for ESC: } \\
\text { PDI }_{A B}\end{array}$ & Difference between indices of power distance of countries $A$ and \\
\hline$I D V_{A B}$ & B \\
\hline $\mathrm{MAS}_{\mathrm{AB}}$ & Difference between indices of individualism of countries $A$ and $B$ \\
\hline $\mathrm{UAl}_{\mathrm{AB}}$ & $\begin{array}{l}\text { Difference between indices of masculinity of countries } A \text { and } B \\
\text { Difference between indices of uncertainty avoidance of countries }\end{array}$ \\
\hline $\begin{array}{l}\text { only for BSC: } \\
\text { OpennessAB }\end{array}$ & $A$ and $B$ \\
\hline AgreeablenessAB & Difference between indices of Openness of countries A and B \\
\hline ExtraversionAB & Difference between indices of Agreeableness of countries $A$ and \\
\hline NeuroticismAB & B \\
\hline Conscientiousness $A B$ & $\begin{array}{l}\text { Difference between indices of Extraversion of countries A and B } \\
\text { Difference between indices of Neuroticism of countries A and B } \\
\text { Difference between indices of Conscientiousness of countries A } \\
\text { and B }\end{array}$ \\
\hline \multicolumn{2}{|l|}{ Religion } \\
\hline Religion $_{A B}$ & $\begin{array}{l}\text { If Country } A \text { and } B \text { share at the minimum one major religion }=1 \\
\text { Otherwise }=0\end{array}$ \\
\hline
\end{tabular}

Table 5 Possible explanatory variables of voting behavior 


\section{ESTIMATIONS AND DISCUSSION}

\subsection{COMPARING THE ESC RESULTS TO FORMER StUdiES}

In general, the results from our linear voting model confirm the results by Spierdijk and Vellekoop (2009) to the extent that the ESC shows strong significantly biased voting patterns based on geographical proximity. More precisely, voting countries favor their neighbors and are negatively biased toward more distant countries (measured in terms of distance between the two capitals). Furthermore, the longer the common border, the higher the voting bias in favor of other participating countries (see table 7). Since we use a slightly different dataset that, in contrast to Spierdijk and Vellekoop (2009), excludes the early years (1975-1997) but adds the more recent years (2004-2013), this can be viewed to support the robustness of their results. On the contrary, our average neighbor effect is strongly significant. This result can be explained by the fact that public audience voting plays a larger role in our dataset. Remarkably, when looking at our country-specific model (see table 8), no country coherently shows a significant anti-neighbor bias over the three indicators. Spierdijk and Vellekoop's (2009: 417) prime example of antineighbor bias, Macedonia, displays a pro-neighbor bias regarding the neighbor dummy variable and the Capital_Dis variable in our sample, whereas the variable Length_CB border suggests an anti-neighbor bias. The newer data of Macedonia might reflect its re-orientation as an independent country in contrast to trends in older data which could result from its status as a former Yugoslavian republic.

In terms of the influence of religion, our average linear voting model supports the results of Spierdijk and Vellekoop (2009). Countries, that share the same religion, are positively biased toward each other (see table 7). In our country specific model (see table 10 and table 13), our sample again shows considerably more countries with a respective voting bias than Spierdijk and Vellekoop (2009). In line with the literature, all of the biases are in favor of same religions (see table 10). Regarding the cultural dimensions, we get a mixed picture that roughly resembles the results from Spierdijk and Vellekoop (2009), confirming that cultural-biased voting plays a very relevant role for the contest outcomes (see table 14). For example, Denmark is 
significantly influenced by the cultural dimensions of IDV, MAS and UAI. In our average voting model all cultural dimensions significantly influence the voting bias with a negative sign (see table 7). Thus, the closer the participating countries are in terms of culture, the higher the voting bias.

As you can see (e.g. table 7) we estimated our model without including variables as well as with including variables of cultural dimensions. Because the study of Hofstede does not investigate all countries that vote in the ESC, the number of observations drops from 13119 to 7517. All in all, the estimation results remain virtually unchanged even after controlling for cultural aspects (see table 7). Religion also matters, but of course, turns out to be less significant when looking at the countryspecific model.

Against the background of performance aspects, we could not find any influences based on performance characteristics such as gender, order, host or the number of singers. Again, this confirms the results by Spierdijk and Vellekoop (2009). Nevertheless, also the language does not play a significant role anymore. On the contrary, countries that share a common official or primary language are significantly positively biased toward each other (see table 7).

\subsection{VOTING BIAS IN THE BSC}

The first conclusion we can draw from the BSC analysis is that biased voting patterns also exist in the BSC (see tables 15-24) ${ }^{20}$. Thus, biased voting patterns do not only take place among different countries in Europe but also within one of the biggest countries, namely Germany. This conclusion is important because it shows that favoring artists for other than artistic reasons does not depend on nationality and different nations being involved. Secondly, we can extend this result by demonstrating that geographical proximity also matters with respect to the national contest. Thus, even within one and the same nation, effects of (regional) community closeness affect voting patterns (see table 15).

20 Only OLS is discussed here, since the linear model with fixed effects leads to results that are very similar to those estimated. The same holds for the ESC. 
The most obvious case of geographical preferences in voting behavior is the phenomenon of patriotic voting in the BSC. In contrast to the ESC, the BSC allows its audience to vote for their own state. Consequently, German states award themselves around 8 points more than the number of points assigned by all other German states on average throughout all the years (see table 15), leading to significant patriotic voting, displayed in a large bias with positive sign in the case of the BSC (see tables 15 and 17). This actually represents the strongest case of geographically-biased voting. Next to patriotic voting, voting biases in favor of neighboring states also occur in our linear voting model. All in all, German states are positively biased toward their neighbors and they also show a significant negative bias increasing with the distance between the capitals (see table 15). ${ }^{21}$ This remains valid in the country-specific model. Bavaria, Hamburg, Lower Saxony and Saarland are positively biased towards their neighbors (Length_CB) and also Bremen, SchleswigHolstein and Saxony favor their neighbors (Capital_Dis). It is noticeable, however, that the neighbor dummy variable shows an antineighbor bias in most of the significant cases (Hamburg, Lower Saxony and Saxony-Anhalt). Although this seems paradoxical at first sight, there may be specific explanations for this kind of voting behavior. For instance, Hamburg is negatively biased to its neighbors, but shows a positive bias regarding the length of common border and a negative one in terms of the distance to other capitals of German states. Hamburg only has two neighboring German states (Lower Saxony and Schleswig Holstein) and because of Hamburg's voting behavior we might conclude, that there is a special (positive) relationship to Schleswig Holstein, because the length of common border almost doubles the border-length of Lower Saxony and also the distance to Schleswig Holstein's capital is distinctly smaller than the distance to Lower Saxony's capital. Lower Saxony shows similar behavior. Here too, we can look at the neighboring German states and may conclude the favoring of German states that are located to the south of Lower Saxony. Also Saxony-Anhalt is negatively biased to its neighbors. This might be explained by looking at the effect of being a former GDR. When looking at the country-specific model, there is also a special and highly interesting

21 In an alternative version with a re-constructed points allocation excluding own-state votes, the neighboring bias becomes a bit stronger. This version can be supplied upon request. 
effect in the data: the former German divide between a Western and an Eastern republic matters for voting behavior (see tables 16-17). Even in the time-span of 15-23 years after the re-unification, the voting audience in the former GDR-states favors acts from other former GDR-states whereas the voting audience from former FRG-states disfavors acts from former GDR-states. ${ }^{22}$ Four decades of separation (following World War II) may have led to deviations in the cultural heritages of the two German states and that appears to be influencing voting behavior until the present day. The inner re-unification, thus, does not appear to be complete in regard to cultural contest events. Particularly noteworthy in this context is that especially the former GDR-states favor acts from other former GDR-states, e.g Saxony-Anhalt, Saxony and Thuringa are significantly positively biased towards states from the former Eastern part of Germany. Also Bremen, Lower Saxony, North RhineWestphalia and Schleswig-Holstein, which belonged to the former Western part of Germany, are significantly negatively biased to former GDR states. Because SaxonyAnhalt favors the former GDR-states and borders almost completely former GDRstates (Brandenburg, Saxony and Thuringa) except Lower Saxony, the anti-neighbor effect might be attributable to the relationship to Lower Saxony (see table 17). On the aggregate level, the former GDR variable does not significantly influence the voting bias (see table 15). For that reason, the country-specific estimation model reaffirms the importance of capturing voting patterns more precisely.

Regarding performance aspects, we could not find any influences based on performance characteristics such as gender, order, host or the number of singers (see table 15).

In terms of religion, the BSC surprisingly shows other-religion biased voting for several of the Western German states (Hamburg, Schleswig-Holstein, North RhineWestphalia). This stands in contrast to the ESC results and represents an interesting result in particular in the cases where it relates to non-neighboring states or neighboring states that display no geographical proximity bias.

22 GDR = German Democratic Republic (the former Eastern part of Germany); FRG = Federal Republic of Germany (the former Western part of Germany). 
Similar to the ESC case, we also estimated our model with and without variables of the Big Five dimensions (see table 15). Again, our estimation equation leads to very similar results, which also underlines the robustness of our model. Geographical proximity also plays nearly the same role in explaining the voting bias. Thus, neighbor, capital distance and the home-bias variable stay significant at the three star level. The same tendency can be discerned in our country-specific model. Only some of the voting countries turn out to be insignificant in terms of neighborhood (Hamburg, Saxony-Anhalt) and of being a former GDR state (Saxony-Anhalt, Schleswig-Holstein and Saxony) or regarding the home-bias effect (13 out of 16 Germans states turn out to be significant). The only exception is our religious confession variable, which turns out to be insignificant (from a one star level in model (1)) when controlling for cultural dimensions. Therefore, we have to be careful to interpret these results. Pro- or anti-religious confession effects may merely stand for an extended neighborhood-effect. Then, religion would not play any significant role in explaining the voting bias. Regarding the cultural aspects, we get a mixed picture as well, that resembles the results from the ESC, confirming that culturallybiased voting also plays a significant role for the contest outcomes, although cultural differences are much smaller. 


\subsection{COMPARING ESC AND BSC}

\begin{tabular}{l|ll}
\hline \multirow{2}{*}{$\begin{array}{l}\text { Explanatory } \\
\text { Variables }\end{array}$} & $\begin{array}{l}\text { ESC } \\
\text { magnitude of } \\
\text { bias }\end{array}$ & $\begin{array}{l}\text { magnitude of } \\
\text { bias }\end{array}$ \\
\hline Neighb & $52.9 \%$ & $30.77 \%$ \\
Length_CB & $59.1 \%$ & $25 \%$ \\
Capital_Dis & $35.4 \%$ & $31.25 \%$ \\
Language & $40 \%$ & \\
Former GDR & & $43.75 \%$ \\
Home Bias & & $100 \%$ \\
Male_solo & $6.25 \%$ & $6.25 \%$ \\
Duet & $12.5 \%$ & $0 \%$ \\
Group & $8.33 \%$ & $6.25 \%$ \\
English & $37.5 \%$ & \\
French & $6.5 \%$ & \\
Order & $10.4 \%$ & $0 \%$ \\
Host & $0 \%$ & $6.25 \%$ \\
Religion & $39.1 \%$ & $25 \%$ \\
\hline
\end{tabular}

Table 6 Comparison between the magnitude of bias in the ESC and BSC (without cultural aspects) ${ }^{23}$

In general, voting behavior in the ESC and BSC hardly differ from one another (see table 7 and table 15). Table 6 visualizes a comparison of the results by displaying the share of cases in which the respective bias occurred in a significant way in the country-specific model. For instance, in the ESC the variable Neighb was significant in 52.9 per cent of all cases (= of all country-pairs voting for each other), whereas it was 30.8 per cent in the BSC. We choose this way of summarizing the results of the complex country-specific model in order to make the comparison more accessible and more transparent.

Generally, geographical proximity significantly influences voting patterns in both contests. However, the magnitude of biases differs. While the magnitude of bias regarding Capital_Dis is very similar (35.4 per cent in the ESC versus 31.3 per cent in the BSC), voting bias occurs less frequently in the BSC than in the ESC regarding the dummy variable (30.8 per cent to 52.9 per cent) as well as regarding the varia-

23 Because there are hardly any changes when estimating with or without the cultural aspects and also hardly any changes in adj R-squared, we compare our estimation results by using the country-specific model without controlling for culture. 
ble Length_CB (25 per cent to 59.1 per cent). Notwithstanding, one should be careful to conclude a smaller voting bias for the national contest because due to one of the few differences in rules the national contest is additionally characterized by comprehensive patriotic voting (home bias). Unfortunately, we cannot know for whom the patriotic voters in the BSC would have voted if they had not been allowed to vote for their home state. If they had over-proportionally voted for one of their neighbor states, then the non-home neighbor bias would have been increased. This does not seem to be very implausible. Indication supporting this speculation can be drawn from an alternative model that we estimated and in which we re-allocated the BSC-points excluding patriotic voting. ${ }^{24}$ In this model variant, the neighbor bias increases.

It is conspicuous that performance characteristics like duo, group, order, host country and male solo singer for both ESC and BSC do not play any major role, when looking at the average linear voting model in table 7 and table 15. Because we did not measure the language differences in Germany, we cannot compare these results. Unfortunately, we did not find usable data on the closeness of German accents.

Furthermore, cultural similarities also significantly matter for both contests. The Big Five traits and Hofstede's cultural dimensions negatively influence the bias, the higher the difference between their cultural indices are. While all dimensions of Hofstede show a negative sign, German states favor German states that do not show similar indices in Extraversion and Conscientiousness (see table 7, model (2) and 15 model (2)). Religion also matters and influences the voting bias for both of the contests. However, religion turns out to be insignificant for the BSC, when including variables explaining culture (see table 7 and 15).

\footnotetext{
24 Basically, the alternative model with points re-allocation excludes the patriotic voters which does not solve the problem of what the counterfactual votes of the patriotic voters would have looked like. Therefore, we chose not to report and discuss it in detail in this paper. Information can be obtained from the authors upon request.
} 


\section{ConCLusion}

Culturally-biased voting has been a major point of discussion with respect to the ESC. People ostensibly voting for their neighbor countries instead of judging according to musical quality triggered several controversies. It is a common underlying assumption that the international character of the song contest and, thus, the heterogeneity of the participating countries plays an important role in motivating the biases because neighboring countries often are less 'different' than more distant countries and, thus, voters are more sympathetic to and more willing to vote for them. If the cultural bias is driven by the heterogeneity of countries, then it should be less relevant - or not relevant at all - in a national contest with considerably more homogenous participants. However, comparing the voting patterns of the European-wide ESC with the inner-German derivative BSC reveals that geographically biased voting is relevant for national contests as well. In our analysis, we find empirical evidence for the existence of strong geographical voting bias in both contests. Notwithstanding this, bias favoring neighboring countries occurs less frequently in the national contest (BSC) than in the international contest (ESC). On the other hand, however, the BSC-specific phenomenon of patriotic voting implies that overall geographic bias in the national contest is not necessarily smaller than in the international context. Altogether, the comparative homogeneity of participants in the national contest does not erode strong voting bias in favor of geographical proximity compared to the comparatively more heterogeneous participants in the ESC. Moreover, control variables and other potential influences display very similar patterns.

A special result regarding the national contest relates to effects of a common heritage that may add to the geographical proximity preference in particular cases. For the inner-German contest (BSC), the former East-West-German divide (1946-1990) still plays a role in voting patterns even after more than a decade of re-unification. Altogether, geographical voting biases are not exclusive to international contests. Instead, elements of local support appear to represent a fundamental preference of audiences and 'neutral', exclusively 'quality-based' voting cannot be expected even in cases of comparatively homogenous cultural and linguistic traits. 


\section{REFERENCES}

Atkinson, R., L.; Atkinson, R.C.; Smith, E.E.; Bem D.J.; Nolen-Hoeksema, S. (2000), Hilgard's Introduction to Psychology. Orlando, Florida: Harcourt College Publishers.

BRUINE DE BRUIN, W. (2005), Save the last dance for me: unwanted serial position effects in jury evaluations, Acta Psychologica 118, pp. 245-260.

BAKER, C. (2008), Wild Dances and Dying Wolves: Simulation, Essentialization, and National Identity at the Eurovision Song Contest, Popular Communication 6 (3), pp. 178189.

Christensen, M.; Christensen, C. (2008), The After-Life of Eurovision 2003: Turkish and European Social Imaginaries and Ephemeral Communicative Space, Popular Communication 6 (3), pp. 155-172.

Clerides, S.; Stengos, T. (2006), Love thy Neighbor, Love thy Kin: Voting Biases in the Eurovision Song Contest. Discussion Paper 01, University of Cyprus.

Costa, P.T.,JR., McCRAe, R.R. (1992), Revised NEO Personality Inventory (NEO-PI-R) and NEO Five-Factor Inventory (NEO-FFI) Manual. Odessa, FL: Psychological Assessment Resources.

DYEN, I.; KRUSKAL, J.B.; BLACK, P. (1992), An Indo-European classification: A lexicostatistical experiment, Transactions of the American Philosophical Society 82 (5), Philadelphia: American Philosophical Society.

EBU/UER (2013), Rules of the Eurovision Song Contest, http://www.ebu.ch.

Fenn, D.; Suleman, O.; Efstathiou, J.; Johnson, N. (2006), How does Europe make its mind up? Connections, cliques and compatibility between countries in the Eurovision Song Contest, Physica A: Statistical Mechanics and its Applications, 360 (2), pp. 576598.

FleisCher,A.; Felsenstein, D. (2002), Cost-Benefit Analysis Using Economic Surpluses: A Case Study of a Televised Event, Journal of Cultural Economics 26 (2), pp. 139-156.

GathereR, D. (2004), Birth of a Meme: the Origin and Evolution of Collusive Voting Patterns in the Eurovision Song Contest, Journal of Memetics - Evolutionary Models of Information Transmission 8.

GathereR, D. (2006), Comparison of Eurovision Song Contest Simulation with Actual Results Reveals Shifting Patterns of Collusive Voting Alliances, Journal of Artificial Societies and Social Simulation 9 (2).

GARCíA, D.; TANASE, D. (2013), Measuring Cultural Dynamics Through the Eurovision Song Contest. Available at http://arxiv.org/abs/1301.2995 (accessed 2013-05-12). 
Georgiou, M. (2008), "In the End, Germany will Always Resort to Hot Pants": Watching Europe Singing, Constructing the Stereotype, Popular Communication 6 (3), pp. 141154.

Ginsburgh, V.; Noury, A. G. (2008), The Eurovision Song Contest: Is voting political or cultural?, European Journal of Political Economy 24, pp. 41-52.

GleJSER, H.; HeYNDELS, B. (2001), The ranking of finalists in the Queen Elisabeth International music competition, Journal of Cultural Economics 25, pp. 109-129.

HaAn, M. A.; Dijkstra, S. G.; Dijkstra, P.T. (2005), Expert Judgment Versus Public Opinion? Evidence from the Eurovision Song Contest, Journal of Cultural Economics 29, pp. 59-78.

Hofstede, G. (1980), Culture's Consequences, Beverly Hills, California: Sage.

HofStedE, G. (1991), Culture and Organizations, London: McGraw-Hill.

IANNACCONE, L.R. (1998), Introduction to the Economics of Religion, Journal of Economic Literature XXXVI, pp. 1465-1496

KoкKo, A.; Tingvall P. G. (2012), The Eurovision Song Contest, Preferences and European Trade, Ratio Working Paper No. 183.

KRESSLEY, K.M. (1978), Integrated television in Europe: a note on the EUROVISION network, International Organization 32 (4), pp. 1045-1050.

KURAN, T. (1994), Religious economics and the economics of religion, Journal of Institutional and Theoretical Economics 150, pp. 769-775.

Lazarsfeld, P.F.; Berelson, B; Gaudet, H. (1948), The People's Choice: How the Voter Makes Up His Mind in a Presidential Campaign, New York: Columbia University Press.

McCrae, R. R.; Costa, P. T. (1990); Personality in Adulthood, New York: Guilford.

MCCRAE, R.R.; John, O.P. (1992), An introduction to the five-factor model and its applications, Journal of Personality 60, pp. 75-215.

McCrae R. R.; Terracciano, A.; 79 Members of the Personality Profiles of Cultures Project (2005); Personality Profiles of Cultures: Aggregate Personality Traits, Journal of Personality and Social Psychology 89 (3), pp. 407-425.

Obschonka, M.; Schmitt-Rodermund, E.; Silbereisen, R.K.; Gosling, S.D.; Potter, J. (2013), The regional distribution and correlates of an entrepreneurship-prone personality profile in the United States, Germany, and the United Kingdom: A socioecological perspective, SOEPpapers on Multidisciplinary Panel Data Research, No. 550 . 
Renato, F.; Ginsburgh, V. (1996), The Queen Elizabeth musical competition: How fair is the final ranking? Journal of the Royal Statistical Society, Series D, The Statistician 45, pp. 97-104.

SCHWEIGER, W.; Brosius, H. (2003), Eurovision Song Contest - beeinflussen Nachrichtenfaktoren die Punktvergabe durch das Publikum? Medien und Kommunikationswissenschaft 51 (2), pp. 271-294.

SPIERDIJK, L.; VelleKOoP, M. (2009), The structure of bias in peer voting systems: Lessons from the Eurovision Song Contest, Empirical Economics 36, pp. 403-425.

VERRIER, D.B. (2012), Evidence for the influence of the mere-exposure effect on voting in the Eurovision Song Contest, Judgment and Decision Making 7 (5), pp. 639-643.

YAIR, G. (1995), 'Unite Unite Europe' The political and cultural structures of Europe as reflected in the Eurovision Song Contest, Social Networks 17 (2), pp. 147-161.

YaIR, G.; MAMAN, D. (1996), The Persistent Structure of Hegemony in the Eurovision Song Contest, Acta Sociologica 39 (3), pp. 309-325. 


\section{Appendix}

Table 7: Linear Voting Model, Eurovision Song Contest

\begin{tabular}{|c|c|c|}
\hline & (1) & (2) \\
\hline Neighb $_{A B}$ & $\begin{array}{l}1.810^{* * *} \\
(11.44)\end{array}$ & $\begin{array}{c}0.969^{* * *} \\
(4.76)\end{array}$ \\
\hline Length_C $\mathrm{B}_{\mathrm{AB}}$ & $\begin{array}{c}0.000857^{* * *} \\
(3.75)\end{array}$ & $\begin{array}{l}0.00150^{* * *} \\
(4.79)\end{array}$ \\
\hline Capital_Dis ${ }_{A B}$ & $\begin{array}{c}-0.000232^{* * *} \\
(-7.19)\end{array}$ & $\begin{array}{c}-0.000195^{* * *} \\
(-3.87)\end{array}$ \\
\hline Lang $_{A B}$ & $\begin{array}{l}1.589^{* * *} \\
(10.51)\end{array}$ & $\begin{array}{c}0.829^{* * *} \\
(4.70)\end{array}$ \\
\hline Male_solo ${ }_{B t}$ & $\begin{array}{c}0.0218 \\
(0.35)\end{array}$ & $\begin{array}{c}0.0204 \\
(0.26)\end{array}$ \\
\hline Duet $_{B t}$ & $\begin{array}{c}0.0790 \\
(0.81)\end{array}$ & $\begin{array}{c}0.0109 \\
(0.09)\end{array}$ \\
\hline Group $_{\mathrm{Bt}}$ & $\begin{array}{c}0.00316 \\
(0.04)\end{array}$ & $\begin{array}{c}-0.00408 \\
(-0.04)\end{array}$ \\
\hline English $_{B t}$ & $\begin{array}{c}0.0195 \\
(0.36)\end{array}$ & $\begin{array}{l}0.110 \\
(1.55)\end{array}$ \\
\hline French $_{\mathrm{Bt}}$ & $\begin{array}{l}-0.327 \\
(-1.96)\end{array}$ & $\begin{array}{l}-0.355 \\
(-1.91)\end{array}$ \\
\hline Order $_{B t}$ & $\begin{array}{c}0.00118 \\
(0.32)\end{array}$ & $\begin{array}{c}0.00615 \\
(1.32)\end{array}$ \\
\hline Host $_{B t}$ & $\begin{array}{c}-0.000540 \\
(-0.00)\end{array}$ & $\begin{array}{c}-0.0230 \\
(-0.14)\end{array}$ \\
\hline Religion $_{A B}$ & $\begin{array}{c}0.551^{* * *} \\
(8.94)\end{array}$ & $\begin{array}{c}0.274^{* * *} \\
(3.43)\end{array}$ \\
\hline $\mathrm{PDI}_{\mathrm{AB}}$ & & $\begin{array}{c}-0.00544^{* *} \\
(-2.60)\end{array}$ \\
\hline$I D V_{A B}$ & & $\begin{array}{c}-0.00566^{*} \\
(-2.33)\end{array}$ \\
\hline $\mathrm{MAS}_{\mathrm{AB}}$ & & $\begin{array}{c}-0.00604^{* *} \\
(-3.15)\end{array}$ \\
\hline$U A I_{A B}$ & & $\begin{array}{c}-0.00529^{* *} \\
(-2.72)\end{array}$ \\
\hline _cons & $\begin{array}{c}-0.0378 \\
(-0.40)\end{array}$ & $\begin{array}{c}0.466^{* *} \\
(2.86)\end{array}$ \\
\hline$N$ & 13119 & 7517 \\
\hline
\end{tabular}


Table 8: Country-Specific linear voting model, Eurovision Song Contest, 1

\begin{tabular}{|c|c|c|c|c|c|c|c|c|}
\hline Country $_{A}$ & Neighb & & Length_CB & & Capital_Dis & & Lang & \\
\hline Albania & -18.32 & $(-1.95)$ & 0.121 * & $(2.58)$ & -0.000362 & $(-1.34)$ & & \\
\hline Andorra & & & $0.0976 * *$ & (3.08) & 0.000358 & $(0.80)$ & 3.122 & $(1.40)$ \\
\hline Armenia & $3.456^{*}$ & $(2.32)$ & $-0.0105^{* * *}$ & $(-4.70)$ & $-0.000783 * *$ & $(-3.01)$ & & \\
\hline Austria & $-3.650 * *$ & $(-2.83)$ & $0.00734^{* *}$ & (2.99) & $-0.00149 * * *$ & $(-4.60)$ & 0.601 & $(0.70)$ \\
\hline Azerbaijan & $6.419 * * *$ & $(5.43)$ & $-0.0132 * * *$ & $(-6.50)$ & $-0.00136 * * *$ & $(-5.55)$ & & \\
\hline Belarus & -0.977 & $(-0.84)$ & $0.00657^{* * *}$ & $(5.83)$ & 0.000499 & $(1.92)$ & & \\
\hline $\begin{array}{l}\text { Belgium } \\
\text { Bosnia and }\end{array}$ & -0.348 & $(-0.27)$ & $0.00883^{* * *}$ & (3.36) & $0.00104 * * *$ & $(4.43)$ & 0.468 & $(0.56)$ \\
\hline Herzegovina & $5.710 * * *$ & (3.53) & 0.000482 & $(0.23)$ & $-0.00100 * * *$ & $(-4.16)$ & & \\
\hline Bulgaria & $6.632^{* * *}$ & (4.75) & $-0.00821^{*}$ & $(-2.59)$ & 0.000342 & (0.99) & & \\
\hline Croatia & 1.394 & (1.14) & $0.00375^{*}$ & $(2.00)$ & $-0.000735^{* *}$ & $(-2.86)$ & $2.590^{*}$ & $(2.31)$ \\
\hline Cyprus & & & & & 0.000307 & (1.57) & $3.873 * * *$ & $(6.03)$ \\
\hline Czech Republic & 56.95 & $(0.12)$ & -0.0775 & $(-0.12)$ & $0.00171^{* *}$ & (3.25) & & \\
\hline Denmark & & & -0.00741 & $(-1.26)$ & -0.000337 & $(-1.41)$ & & \\
\hline Estonia & $8.235^{*}$ & (1.98) & -0.237 & $(-1.87)$ & $-0.000659 * * *$ & $(-3.37)$ & & \\
\hline Finland & 0.0958 & $(0.04)$ & 0.000823 & $(0.38)$ & -0.000275 & $(-1.06)$ & 2.298 & $(1.61)$ \\
\hline France & 0.106 & $(0.04)$ & 0.00192 & $(0.41)$ & $0.00124^{* * *}$ & $(4.67)$ & 0.990 & $(0.93)$ \\
\hline Georgia & $4.400 *$ & $(2.58)$ & -0.00376 & $(-1.45)$ & $-0.000835^{*}$ & $(-2.32)$ & & \\
\hline Germany & 1.167 & (1.33) & -0.000356 & $(-0.20)$ & 0.000221 & $(0.89)$ & 0.177 & $(0.23)$ \\
\hline Greece & -3.516 & $(-1.61)$ & $0.0212^{*}$ & $(2.20)$ & -0.000194 & $(-0.85)$ & $9.744^{* * *}$ & $(9.45)$ \\
\hline Hungary & 0.386 & $(0.34)$ & 0.00103 & $(0.29)$ & 0.000540 & $(1.48)$ & & \\
\hline Iceland & & & & & $-0.000617 * * *$ & $(-3.49)$ & & \\
\hline Ireland & & & 0.00155 & $(0.64)$ & $-0.00111 * * *$ & $(-4.85)$ & 1.311 & $(1.88)$ \\
\hline Israel & & & & & 0.000192 & $(1.32)$ & -0.559 & $(-1.15)$ \\
\hline Italy & -8.541 & $(-1.32)$ & 0.0150 & $(0.98)$ & $-0.00197 * *$ & $(-2.98)$ & -4.450 & $(-0.77)$ \\
\hline Latvia & $2.914^{*}$ & $(2.13)$ & 0.00464 & $(1.31)$ & -0.000294 & $(-1.22)$ & & \\
\hline Lithuania & $3.947 * * *$ & (3.48) & 0.00251 & $(0.90)$ & -0.0000411 & $(-0.16)$ & & \\
\hline Macedonia & $8.184^{* * *}$ & (5.74) & $-0.0356^{* * *}$ & $(-4.91)$ & $-0.00156^{* * *}$ & $(-5.90)$ & & \\
\hline Malta & & & & & 0.000231 & $(1.00)$ & $1.705^{* *}$ & (3.25) \\
\hline Moldova & & & $0.00477^{* * *}$ & $(4.84)$ & 0.000338 & (1.14) & $6.880 * * *$ & $(7.24)$ \\
\hline Monaco & & & $1.590 *$ & (2.59) & -0.000167 & $(-0.19)$ & & \\
\hline Montenegro & $5.038^{* *}$ & $(2.71)$ & 0.00976 & $(0.94)$ & -0.000235 & $(-0.66)$ & -1.186 & $(-0.86)$ \\
\hline Netherlands & & & $0.00368^{* *}$ & $(2.78)$ & 0.000326 & $(1.44)$ & $4.099 * * *$ & (3.38) \\
\hline Norway & $-1.786^{*}$ & $(-2.20)$ & $0.00300^{* * *}$ & (3.90) & -0.000160 & $(-0.71)$ & & \\
\hline Poland & -0.886 & $(-0.85)$ & $0.00633^{*}$ & $(2.48)$ & -0.000355 & $(-1.42)$ & & \\
\hline Portugal & & & $0.00458^{* * *}$ & $(5.46)$ & -0.000370 & $(-1.22)$ & & \\
\hline Romania & $19.95^{* *}$ & $(2.89)$ & $-0.0403^{* *}$ & $(-2.90)$ & -0.000457 & $(-1.76)$ & $7.452 * * *$ & $(5.52)$ \\
\hline Russia & $1.533^{*}$ & $(2.29)$ & 0.000656 & $(1.08)$ & 0.000218 & $(0.74)$ & & \\
\hline San Marino & & & 0.0942 & $(0.94)$ & 0.0000140 & $(0.03)$ & 0.0182 & $(0.01)$ \\
\hline $\begin{array}{l}\text { Serbia } \\
\text { Serbia and }\end{array}$ & $8.116^{* * *}$ & $(5.55)$ & $-0.0186^{* * *}$ & $(-4.67)$ & -0.000446 & $(-1.29)$ & $3.937^{* * *}$ & (3.49) \\
\hline Montenegro & $7.843^{* * *}$ & (5.14) & $-0.0206 * * *$ & $(-5.03)$ & $-0.00160^{*}$ & $(-2.64)$ & 2.221 & $(1.81)$ \\
\hline Slovakia & 0.954 & $(0.54)$ & 0.000739 & $(0.18)$ & 0.0000623 & $(0.14)$ & & \\
\hline Slovenia & $-4.167 * * *$ & $(-3.32)$ & $0.0198^{* * *}$ & $(5.54)$ & $-0.00187^{* * *}$ & $(-7.91)$ & & \\
\hline Spain & -3.273 & $(-1.43)$ & 0.00541 * & $(2.17)$ & -0.0000132 & $(-0.05)$ & & \\
\hline Sweden & & & $0.00177^{* * *}$ & (3.45) & -0.0000899 & $(-0.41)$ & $3.145^{* *}$ & (3.25) \\
\hline Switzerland & $5.898^{* *}$ & $(2.83)$ & $-0.00834^{*}$ & $(-2.43)$ & $-0.00122 * * *$ & $(-3.69)$ & -0.575 & $(-0.42)$ \\
\hline Turkey & 1.529 & $(1.03)$ & 0.00508 & $(0.72)$ & -0.0000950 & $(-0.47)$ & -1.251 & $(-1.25)$ \\
\hline Ukraine & -1.285 & $(-1.38)$ & $0.00504^{* * *}$ & $(5.63)$ & 0.0000455 & $(0.15)$ & & \\
\hline United Kingdom & & & $0.00726^{*}$ & $(2.42)$ & -0.000420 & $(-1.91)$ & $2.061 * *$ & $(3.16)$ \\
\hline
\end{tabular}

$t$ statistics in parentheses, ${ }^{*} p<0.05,{ }^{* *} p<0.01,{ }^{* * *} p<0.001$ 
Table 9: Country-Specific linear voting model, Eurovision Song Contest, continued 2

\begin{tabular}{|c|c|c|c|c|c|c|c|c|c|c|}
\hline Country $_{A}$ & Male_solo & & Duet & & Group & & English & & French & \\
\hline Albania & 0.572 & $(1.33)$ & 0.472 & $(0.68)$ & -0.333 & $(-0.61)$ & -0.514 & $(-1.31)$ & -0.0464 & $(-0.03)$ \\
\hline Andorra & -0.488 & $(-0.80)$ & -0.101 & $(-0.11)$ & 0.251 & $(0.36)$ & 0.250 & $(0.47)$ & -3.854 & $(-1.59)$ \\
\hline Armenia & -0.0342 & $(-0.06)$ & 1.079 & $(1.25)$ & -1.341 & $(-1.90)$ & 0.192 & $(0.39)$ & $3.653^{*}$ & $(2.08)$ \\
\hline Austria & 0.289 & $(0.66)$ & -0.158 & $(-0.23)$ & 0.0921 & $(0.17)$ & $-1.307 * * *$ & $(-3.45)$ & -1.127 & $(-0.99)$ \\
\hline Azerbaijan & -0.309 & $(-0.61)$ & 1.196 & (1.29) & -0.235 & $(-0.31)$ & 0.345 & $(0.75)$ & -0.840 & $(-0.45)$ \\
\hline Belarus & -0.226 & $(-0.63)$ & -0.0775 & $(-0.13)$ & 0.291 & $(0.64)$ & $0.937^{* *}$ & $(2.89)$ & 1.570 & $(1.29)$ \\
\hline Belgium & -0.326 & $(-0.95)$ & $-1.199 *$ & $(-2.24)$ & 0.111 & $(0.26)$ & -0.0396 & $(-0.13)$ & $-4.384^{* * *}$ & $(-3.72)$ \\
\hline $\begin{array}{l}\text { Bosnia and } \\
\text { Herzegovina }\end{array}$ & -0.0174 & $(-0.05)$ & 0.0581 & $(0.10)$ & -0.422 & $(-0.91)$ & -0.624 & $(-1.89)$ & 1.702 & $(1.73)$ \\
\hline Bulgaria & 0.180 & $(0.39)$ & -0.855 & $(-1.14)$ & 0.196 & $(0.34)$ & $1.035^{*}$ & $(2.47)$ & 0.211 & $(0.14)$ \\
\hline Croatia & -0.236 & $(-0.70)$ & 0.376 & $(0.73)$ & -0.368 & $(-0.87)$ & -0.303 & $(-1.02)$ & -1.213 & $(-1.44)$ \\
\hline Cyprus & 0.0908 & $(0.25)$ & $1.158^{*}$ & $(2.05)$ & -0.885 & $(-1.94)$ & 0.235 & $(0.74)$ & 0.0694 & $(0.08)$ \\
\hline $\begin{array}{l}\text { Czech Re- } \\
\text { public }\end{array}$ & -0.319 & $(-0.36)$ & 1.857 & $(1.54)$ & -0.229 & $(-0.22)$ & $-1.639 *$ & $(-2.27)$ & -1.637 & $(-0.55)$ \\
\hline Denmark & 0.424 & $(1.16)$ & 0.0326 & $(0.06)$ & 0.334 & $(0.74)$ & $0.971 * *$ & $(2.97)$ & 1.250 & $(1.30)$ \\
\hline Estonia & 0.0846 & $(0.28)$ & 0.0763 & $(0.16)$ & 0.455 & $(1.13)$ & 0.234 & $(0.85)$ & 0.339 & $(0.45)$ \\
\hline Finland & 0.100 & $(0.26)$ & -0.499 & $(-0.80)$ & 0.0899 & $(0.18)$ & -0.751 * & $(-2.19)$ & 0.893 & $(0.95)$ \\
\hline France & $0.961 *$ & $(2.56)$ & -0.572 & $(-0.99)$ & 0.582 & $(1.22)$ & $-2.107^{* * *}$ & $(-6.32)$ & -0.516 & $(-0.26)$ \\
\hline Georgia & -0.0802 & $(-0.15)$ & 0.984 & $(1.07)$ & $-1.556^{*}$ & $(-2.10)$ & 0.457 & $(0.95)$ & -0.920 & $(-0.33)$ \\
\hline Germany & 0.164 & $(0.46)$ & $-1.113^{*}$ & $(-2.04)$ & 0.00465 & $(0.01)$ & $-0.793^{*}$ & $(-2.53)$ & -1.412 & $(-1.49)$ \\
\hline Greece & 0.294 & $(0.86)$ & 0.481 & $(0.87)$ & -0.164 & $(-0.36)$ & -0.138 & $(-0.45)$ & 1.023 & $(1.13)$ \\
\hline Hungary & -0.132 & $(-0.28)$ & 0.816 & $(1.01)$ & -0.499 & $(-0.80)$ & 0.639 & $(1.54)$ & -0.749 & $(-0.52)$ \\
\hline Iceland & 0.0941 & $(0.27)$ & 0.623 & (1.15) & 0.126 & $(0.29)$ & 0.262 & $(0.83)$ & 1.098 & $(1.12)$ \\
\hline Ireland & -0.106 & $(-0.28)$ & 0.157 & $(0.27)$ & 0.149 & $(0.32)$ & $1.432 * * *$ & $(4.30)$ & 0.159 & $(0.16)$ \\
\hline Israel & -0.820 * & $(-2.39)$ & 0.124 & $(0.23)$ & -0.379 & $(-0.88)$ & $0.711^{*}$ & $(2.33)$ & 0.644 & $(0.76)$ \\
\hline Italy & -0.709 & $(-0.80)$ & -2.501 & $(-1.33)$ & $3.238^{*}$ & $(2.36)$ & 0.350 & $(0.39)$ & & \\
\hline Latvia & 0.0193 & $(0.06)$ & 0.641 & $(1.17)$ & 0.0331 & $(0.07)$ & 0.250 & $(0.80)$ & 0.522 & $(0.57)$ \\
\hline Lithuania & -0.0512 & $(-0.13)$ & 0.170 & $(0.28)$ & 0.0824 & $(0.17)$ & $0.983^{* *}$ & $(2.81)$ & 1.055 & $(0.92)$ \\
\hline Macedonia & -0.642 & $(-1.67)$ & 0.962 & $(1.60)$ & $-0.996^{*}$ & $(-2.01)$ & -0.214 & $(-0.62)$ & -0.490 & $(-0.52)$ \\
\hline Malta & -0.343 & $(-0.93)$ & $1.489 * *$ & $(2.65)$ & $-1.089^{*}$ & $(-2.33)$ & $1.429 * * *$ & $(4.31)$ & -0.219 & $(-0.24)$ \\
\hline Moldova & 0.154 & $(0.38)$ & 0.749 & $(1.15)$ & 0.296 & $(0.59)$ & $0.703^{*}$ & (1.98) & 0.00386 & $(0.00)$ \\
\hline Monaco & 1.055 & $(1.01)$ & -0.981 & $(-0.55)$ & 0.742 & $(0.63)$ & -0.257 & $(-0.27)$ & -8.865 & $(-1.96)$ \\
\hline Montenegro & 0.211 & $(0.43)$ & -0.106 & $(-0.12)$ & 0.550 & $(0.80)$ & -0.555 & $(-1.23)$ & -1.193 & $(-0.51)$ \\
\hline Netherlands & 0.208 & $(0.59)$ & -0.683 & $(-1.25)$ & -0.0942 & $(-0.21)$ & -0.419 & $(-1.37)$ & -0.231 & $(-0.24)$ \\
\hline Norway & 0.467 & $(1.34)$ & -0.608 & $(-1.13)$ & 0.271 & $(0.62)$ & $0.619^{*}$ & $(2.02)$ & $1.811^{*}$ & $(1.98)$ \\
\hline Poland & -0.0750 & $(-0.20)$ & 0.895 & $(1.57)$ & -0.0798 & $(-0.17)$ & -0.282 & $(-0.87)$ & 0.570 & $(0.58)$ \\
\hline Portugal & 0.364 & $(0.90)$ & 0.664 & $(1.05)$ & 0.0989 & $(0.20)$ & -0.511 & $(-1.42)$ & 0.251 & $(0.22)$ \\
\hline Romania & -0.0131 & $(-0.03)$ & $1.350^{*}$ & $(2.22)$ & -0.231 & $(-0.47)$ & -0.257 & $(-0.77)$ & 0.143 & $(0.16)$ \\
\hline Russia & -0.134 & $(-0.33)$ & 0.512 & $(0.81)$ & -0.515 & $(-0.99)$ & -0.0182 & $(-0.05)$ & 0.445 & $(0.42)$ \\
\hline San Marino & 0.113 & $(0.15)$ & -0.733 & $(-0.50)$ & 0.789 & $(0.68)$ & -1.156 & $(-1.57)$ & & \\
\hline Serbia & -0.509 & $(-1.11)$ & -0.489 & $(-0.65)$ & -1.087 & $(-1.77)$ & 0.415 & $(0.99)$ & 1.862 & $(1.04)$ \\
\hline $\begin{array}{l}\text { Serbia and } \\
\text { Montenegro }\end{array}$ & -0.379 & $(-0.56)$ & -0.665 & $(-0.60)$ & -1.083 & $(-1.48)$ & 0.129 & $(0.22)$ & 0.692 & $(0.41)$ \\
\hline Slovakia & 0.404 & $(0.61)$ & -1.722 & $(-1.45)$ & 1.880 & (1.79) & 0.208 & $(0.35)$ & -0.480 & $(-0.29)$ \\
\hline Slovenia & $0.698^{*}$ & $(2.15)$ & -0.453 & $(-0.89)$ & 0.665 & $(1.58)$ & $-0.678^{*}$ & $(-2.41)$ & 0.385 & $(0.44)$ \\
\hline Spain & 0.303 & $(0.83)$ & $1.252^{*}$ & $(2.22)$ & -0.182 & $(-0.39)$ & $-0.751 *$ & $(-2.32)$ & -0.457 & $(-0.41)$ \\
\hline Sweden & 0.244 & $(0.71)$ & 0.160 & $(0.31)$ & -0.177 & $(-0.41)$ & 0.339 & $(1.14)$ & 0.0296 & $(0.04)$ \\
\hline Switzerland & 0.128 & $(0.31)$ & -0.236 & $(-0.35)$ & -0.417 & $(-0.76)$ & $-1.720 * * *$ & $(-4.65)$ & -1.859 & $(-1.46)$ \\
\hline Turkey & -0.298 & $(-0.81)$ & 0.0235 & $(0.04)$ & -0.166 & $(-0.37)$ & 0.289 & $(0.91)$ & -0.596 & $(-0.69)$ \\
\hline Ukraine & -0.104 & $(-0.26)$ & 0.489 & $(0.75)$ & 0.0615 & $(0.12)$ & -0.0410 & $(-0.11)$ & -0.495 & $(-0.39)$ \\
\hline $\begin{array}{l}\text { United King- } \\
\text { dom }\end{array}$ & 0.0710 & $(0.20)$ & -0.674 & $(-1.28)$ & 0.820 & (1.89) & $1.346^{* * *}$ & $(4.47)$ & 0.649 & $(0.75)$ \\
\hline
\end{tabular}

$t$ statistics in parentheses, ${ }^{*} p<0.05,{ }^{* *} p<0.01,{ }^{* * *} p<0.001$ 
Table 10: Country-Specific linear voting model, Eurovision Song Contest, continued 3

\begin{tabular}{|c|c|c|c|c|c|c|c|c|c|}
\hline Country $_{A}$ & Order & & Host & & Religion & & cons & & $\mathrm{N}$ \\
\hline Albania & -0.0175 & $(-0.68)$ & -0.598 & $(-0.65)$ & $3.443 * * *$ & $(5.44)$ & 0.202 & $(0.33)$ & 242 \\
\hline Andorra & 0.0254 & $(0.70)$ & -0.285 & $(-0.23)$ & $1.547^{*}$ & $(2.09)$ & -2.198 & $(-1.83)$ & 146 \\
\hline Armenia & 0.0302 & $(0.92)$ & 0.961 & $(0.83)$ & & & 1.755 & $(1.96)$ & 168 \\
\hline Austria & 0.0275 & $(1.06)$ & -0.419 & $(-0.47)$ & -0.176 & $(-0.42)$ & $2.219 * * *$ & $(3.43)$ & 240 \\
\hline Azerbaijan & 0.0301 & $(0.97)$ & -1.168 & $(-0.97)$ & -0.984 & $(-1.15)$ & $3.431 * * *$ & $(3.56)$ & 146 \\
\hline Belarus & 0.0111 & $(0.51)$ & -0.235 & $(-0.31)$ & -0.0344 & $(-0.10)$ & $-2.139 * * *$ & $(-3.52)$ & 245 \\
\hline $\begin{array}{l}\text { Belgium } \\
\text { Bosnia and Her- }\end{array}$ & -0.00948 & $(-0.47)$ & 0.185 & $(0.26)$ & $0.924^{*}$ & $(2.38)$ & $-1.869 * *$ & $(-2.99)$ & 362 \\
\hline zegovina & -0.0146 & $(-0.67)$ & -0.0933 & $(-0.12)$ & $2.694^{* * *}$ & $(4.67)$ & $1.538^{* *}$ & $(2.88)$ & 305 \\
\hline Bulgaria & $-0.0647^{*}$ & $(-2.31)$ & 0.767 & $(0.78)$ & 0.797 & $(1.52)$ & -1.156 & $(-1.53)$ & 223 \\
\hline Croatia & -0.0223 & $(-1.13)$ & 0.189 & $(0.27)$ & -0.0968 & $(-0.30)$ & $1.148^{*}$ & $(2.00)$ & 382 \\
\hline Cyprus & $-0.0628^{* *}$ & $(-2.99)$ & 0.0867 & $(0.12)$ & $1.777^{* * *}$ & $(4.67)$ & -0.769 & $(-1.25)$ & 361 \\
\hline Czech Republic & 0.0269 & $(0.54)$ & 2.443 & $(1.40)$ & -0.557 & $(-0.66)$ & -2.077 & $(-1.67)$ & 74 \\
\hline Denmark & 0.00312 & $(0.15)$ & 0.622 & $(0.80)$ & $2.939 * * *$ & $(6.80)$ & -1.023 & $(-1.84)$ & 330 \\
\hline Estonia & -0.00352 & $(-0.20)$ & -0.416 & $(-0.63)$ & $1.912^{* * *}$ & $(5.30)$ & 0.107 & $(0.20)$ & 383 \\
\hline Finland & -0.00327 & $(-0.14)$ & -1.276 & $(-1.51)$ & $2.107 * * *$ & $(4.49)$ & 0.276 & $(0.41)$ & 312 \\
\hline France & 0.00412 & $(0.19)$ & -0.0113 & $(-0.01)$ & $1.265^{* *}$ & $(2.78)$ & $-1.892 * *$ & $(-2.60)$ & 377 \\
\hline Georgia & -0.0562 & $(-1.77)$ & -0.554 & $(-0.48)$ & -0.526 & $(-0.74)$ & $2.613^{*}$ & $(2.08)$ & 146 \\
\hline Germany & $0.0411^{*}$ & $(2.02)$ & 1.417 & $(1.89)$ & -0.427 & $(-1.13)$ & -0.314 & $(-0.59)$ & 377 \\
\hline Greece & 0.00497 & $(0.25)$ & -0.391 & $(-0.53)$ & $0.805^{*}$ & $(2.15)$ & -0.209 & $(-0.37)$ & 332 \\
\hline Hungary & 0.0568 & $(1.95)$ & -0.985 & $(-0.98)$ & -0.284 & $(-0.66)$ & $-1.653^{*}$ & $(-2.31)$ & 194 \\
\hline Iceland & -0.0371 & $(-1.82)$ & -0.0982 & $(-0.14)$ & $2.637 * * *$ & $(6.47)$ & $1.413^{*}$ & $(2.00)$ & 333 \\
\hline Ireland & -0.0292 & $(-1.31)$ & -1.248 & $(-1.61)$ & 0.0189 & $(0.05)$ & $1.684^{*}$ & $(2.33)$ & 357 \\
\hline Israel & -0.0283 & $(-1.42)$ & -1.000 & $(-1.38)$ & -0.404 & $(-0.15)$ & -0.161 & $(-0.31)$ & 382 \\
\hline Italy & 0.0235 & $(0.44)$ & 0.248 & $(0.13)$ & -0.0227 & $(-0.02)$ & 2.797 & $(2.00)$ & 74 \\
\hline Latvia & 0.00333 & $(0.16)$ & -0.746 & $(-1.00)$ & $1.318^{* * *}$ & (3.41) & -0.626 & $(-1.02)$ & 337 \\
\hline Lithuania & 0.0127 & $(0.54)$ & 0.310 & $(0.38)$ & 0.532 & $(1.49)$ & $-1.400^{*}$ & $(-2.29)$ & 309 \\
\hline Macedonia & -0.00147 & $(-0.07)$ & 0.471 & $(0.59)$ & -0.314 & $(-0.74)$ & $2.597 * * *$ & $(4.47)$ & 313 \\
\hline Malta & -0.0370 & $(-1.73)$ & -0.556 & $(-0.73)$ & -0.0113 & $(-0.03)$ & -0.716 & $(-1.22)$ & 381 \\
\hline Moldova & 0.00815 & $(0.34)$ & 1.364 & $(1.62)$ & $1.022^{*}$ & $(2.27)$ & $-2.172 * *$ & $(-3.21)$ & 216 \\
\hline Monaco & 0.00385 & $(0.06)$ & 0.286 & $(0.13)$ & 1.673 & $(1.39)$ & -1.023 & $(-0.55)$ & 72 \\
\hline Montenegro & -0.0259 & $(-0.86)$ & 0.449 & $(0.42)$ & 0.527 & $(0.99)$ & -0.0380 & $(-0.05)$ & 126 \\
\hline Netherlands & 0.0123 & $(0.59)$ & 0.590 & $(0.80)$ & -0.00580 & $(-0.02)$ & -0.606 & $(-0.98)$ & 362 \\
\hline Norway & -0.0178 & $(-0.86)$ & 0.144 & $(0.19)$ & $2.084^{* * *}$ & $(4.66)$ & -0.591 & $(-0.99)$ & 356 \\
\hline Poland & $0.0638^{* *}$ & $(2.85)$ & 0.895 & (1.15) & -0.0304 & $(-0.09)$ & -0.550 & $(-0.94)$ & 287 \\
\hline Portugal & 0.0292 & $(1.22)$ & -0.397 & $(-0.47)$ & 0.160 & $(0.32)$ & 0.345 & $(0.32)$ & 312 \\
\hline Romania & 0.0176 & $(0.79)$ & 0.295 & $(0.38)$ & 0.538 & $(1.28)$ & 0.114 & $(0.19)$ & 333 \\
\hline Russia & 0.0240 & $(1.02)$ & -1.602 & $(-1.84)$ & $0.822^{*}$ & $(1.97)$ & -1.129 & $(-1.33)$ & 331 \\
\hline San Marino & -0.0454 & $(-0.98)$ & -1.380 & $(-0.81)$ & 0.331 & $(0.42)$ & 0.926 & $(0.80)$ & 102 \\
\hline Serbia & -0.0110 & $(-0.40)$ & -1.161 & $(-1.11)$ & 0.864 & $(1.83)$ & 0.302 & $(0.40)$ & 171 \\
\hline tenegro & -0.0390 & $(-0.93)$ & 0.0277 & $(0.02)$ & & & $2.249^{*}$ & $(2.14)$ & 70 \\
\hline Slovakia & 0.0192 & $(0.48)$ & -1.018 & $(-0.70)$ & 0.347 & $(0.54)$ & -1.000 & $(-0.97)$ & 125 \\
\hline Slovenia & -0.00736 & $(-0.38)$ & 0.197 & $(0.29)$ & $-1.236^{* * *}$ & $(-4.02)$ & $2.912^{* * *}$ & $(5.70)$ & 362 \\
\hline Spain & $0.0595^{* *}$ & $(2.78)$ & -1.347 & $(-1.80)$ & 0.555 & $(1.23)$ & -0.735 & $(-0.82)$ & 377 \\
\hline Sweden & -0.0128 & $(-0.65)$ & 0.865 & $(1.17)$ & $1.759 * * *$ & $(4.18)$ & -0.516 & $(-0.92)$ & 378 \\
\hline Switzerland & 0.0106 & $(0.43)$ & 0.361 & $(0.41)$ & 0.0389 & $(0.08)$ & $2.582^{* * *}$ & $(3.38)$ & 315 \\
\hline Turkey & -0.0213 & $(-1.00)$ & 0.903 & (1.18) & $5.413 * * *$ & (7.96) & -0.0883 & $(-0.15)$ & 353 \\
\hline Ukraine & 0.0223 & $(0.93)$ & -0.257 & $(-0.29)$ & -0.591 & $(-1.33)$ & -0.556 & $(-0.78)$ & 263 \\
\hline United Kingdom & 0.0266 & $(1.32)$ & -0.563 & $(-0.78)$ & 0.346 & $(0.91)$ & -0.955 & $(-1.55)$ & 377 \\
\hline
\end{tabular}

$t$ statistics in parentheses, ${ }^{*} p<0.05,{ }^{* *} p<0.01,{ }^{* * *} p<0.001$ 
Table 11: Country-Specific linear voting model, Eurovision Song Contest including cultural dimensions 1

\begin{tabular}{|c|c|c|c|c|c|c|c|c|}
\hline & Neighb & & Length_CB & & Capital_Dis & & Lang & \\
\hline Austria & $-4.627^{* * *}$ & $(-3.77)$ & $0.00691 * *$ & $(3.04)$ & $-0.00166^{* *}$ & $(-3.05)$ & 0.398 & $(0.49)$ \\
\hline Belgium & -1.057 & $(-0.84)$ & $0.00868^{* *}$ & (3.23) & $0.00234^{* * *}$ & $(5.12)$ & $2.662^{* *}$ & (2.95) \\
\hline Bulgaria & $6.532 * * *$ & (3.66) & $-0.00819^{*}$ & $(-1.98)$ & 0.000369 & $(0.63)$ & & \\
\hline Croatia & -5.776 & $(-1.83)$ & $0.0198^{* *}$ & (3.24) & 0.000117 & $(0.29)$ & $6.981 * * *$ & $(3.85)$ \\
\hline Czech Republic & 71.27 & $(0.21)$ & -0.0986 & $(-0.20)$ & 0.000857 & $(1.30)$ & & \\
\hline Denmark & & & 0.0106 & (1.57) & 0.000748 & $(1.83)$ & & \\
\hline Estonia & $119.6^{* *}$ & $(2.64)$ & $-0.350 *$ & $(-2.53)$ & $-0.000916^{* * *}$ & $(-3.63)$ & & \\
\hline Finland & 0.159 & $(0.06)$ & 0.000786 & $(0.32)$ & $-0.000716^{*}$ & $(-2.09)$ & 2.756 & $(1.78)$ \\
\hline France & 2.633 & $(1.00)$ & -0.00179 & $(-0.35)$ & $0.00188^{* * *}$ & $(3.40)$ & 1.529 & (1.39) \\
\hline Germany & 1.966 & $(1.80)$ & -0.00102 & $(-0.51)$ & $0.000779^{*}$ & $(2.10)$ & -0.596 & $(-0.71)$ \\
\hline Greece & $-6.822 * *$ & $(-3.24)$ & $0.0291 * *$ & (3.30) & -0.000344 & $(-1.21)$ & & \\
\hline Hungary & -1.637 & $(-0.87)$ & 0.000733 & $(0.17)$ & $-0.00124^{*}$ & $(-1.99)$ & & \\
\hline Ireland & & & $0.0126^{* *}$ & (3.03) & 0.000316 & $(0.73)$ & -0.408 & $(-0.47)$ \\
\hline Israel & & & & & $0.000591 *$ & $(2.55)$ & -0.562 & $(-0.97)$ \\
\hline Italy & -10.51 & $(-1.21)$ & 0.0194 & $(0.94)$ & -0.00127 & $(-0.96)$ & -5.741 & $(-0.82)$ \\
\hline Latvia & $6.276^{* *}$ & (3.13) & -0.00252 & $(-0.45)$ & -0.0000155 & $(-0.04)$ & & \\
\hline Lithuania & $4.533^{* *}$ & (3.07) & 0.00457 & (1.16) & -0.000264 & $(-0.77)$ & & \\
\hline Malta & & & & & -0.000556 & $(-1.48)$ & $1.812^{* *}$ & (2.69) \\
\hline Netherlands & & & 0.00237 & $(1.70)$ & 0.000316 & $(0.88)$ & $5.461 * * *$ & $(4.21)$ \\
\hline Norway & $-2.415^{\star *}$ & $(-2.74)$ & $0.00357^{* * *}$ & (4.19) & -0.0000452 & $(-0.14)$ & & \\
\hline Poland & 0.0815 & $(0.08)$ & -0.00175 & $(-0.56)$ & $-0.000879 * *$ & $(-2.74)$ & & \\
\hline Portugal & & & $0.00442^{* * *}$ & $(4.61)$ & $-0.000910^{*}$ & $(-2.01)$ & & \\
\hline Romania & $25.46^{* *}$ & $(2.67)$ & $-0.0526^{* *}$ & $(-2.62)$ & -0.000739 & $(-1.96)$ & & \\
\hline Russia & 1.253 & $(1.72)$ & -0.00147 & $(-1.35)$ & -0.0000588 & $(-0.17)$ & & \\
\hline Serbia & $5.529 *$ & $(2.23)$ & $-0.0156^{*}$ & $(-2.38)$ & -0.00000654 & $(-0.01)$ & 2.793 & $(1.16)$ \\
\hline Slovakia & -1.029 & $(-0.25)$ & 0.00431 & $(0.62)$ & -0.000308 & $(-0.37)$ & & \\
\hline Slovenia & -2.319 & $(-1.58)$ & $0.0153^{* * *}$ & (3.53) & $-0.00202 * * *$ & $(-5.18)$ & & \\
\hline Spain & -3.457 & $(-1.48)$ & 0.00497 & (1.95) & -0.00112 & $(-1.87)$ & & \\
\hline Sweden & & & $0.00185^{* * *}$ & (3.48) & -0.0000451 & $(-0.15)$ & $3.493^{* * *}$ & (3.74) \\
\hline Switzerland & 3.868 & $(1.89)$ & -0.00539 & $(-1.62)$ & -0.000613 & $(-1.15)$ & 1.013 & $(0.72)$ \\
\hline Turkey & -9.433 & $(-0.54)$ & 0.0550 & $(0.66)$ & 0.000486 & $(1.36)$ & & \\
\hline United Kingdom & & & $0.0146^{* * *}$ & $(3.67)$ & 0.000271 & $(0.74)$ & 0.504 & $(0.65)$ \\
\hline
\end{tabular}

$t$ statistics in parentheses, ${ }^{*} p<0.05,{ }^{* *} p<0.01,{ }^{* * *} p<0.001$ 
Table 12: Country-Specific linear voting model, Eurovision Song Contest including cultural dimensions, continued 2

\begin{tabular}{|c|c|c|c|c|c|c|c|c|c|c|}
\hline & Male_solo & & Duet & & Group & & English & & French & \\
\hline Austria & -0.0926 & $(-0.20)$ & -0.670 & $(-0.96)$ & -0.0843 & $(-0.15)$ & $-1.081 *$ & $(-2.44)$ & -1.398 & $(-1.32)$ \\
\hline Belgium & -0.226 & $(-0.60)$ & -1.147 & $(-1.96)$ & 0.207 & $(0.44)$ & 0.165 & $(0.46)$ & $-4.264 * * *$ & $(-3.73)$ \\
\hline Bulgaria & 0.270 & $(0.52)$ & -0.654 & $(-0.74)$ & 0.386 & $(0.60)$ & 0.819 & $(1.56)$ & 0.658 & $(0.42)$ \\
\hline Croatia & -0.116 & $(-0.33)$ & -0.0907 & $(-0.17)$ & -0.0304 & $(-0.07)$ & 0.0614 & $(0.17)$ & -0.771 & $(-0.91)$ \\
\hline Czech Republic & -0.547 & $(-0.69)$ & 1.352 & $(1.42)$ & 0.664 & $(0.73)$ & -1.170 & $(-1.75)$ & -1.063 & $(-0.49)$ \\
\hline Denmark & 0.0962 & $(0.24)$ & -0.0880 & $(-0.14)$ & 0.139 & $(0.29)$ & $1.334^{* * *}$ & (3.57) & 0.547 & $(0.54)$ \\
\hline Estonia & -0.0205 & $(-0.06)$ & -0.250 & $(-0.47)$ & 0.726 & $(1.63)$ & -0.00502 & $(-0.02)$ & -0.128 & $(-0.17)$ \\
\hline Finland & -0.163 & $(-0.36)$ & -0.969 & $(-1.30)$ & -0.0774 & $(-0.13)$ & -0.755 & $(-1.72)$ & 0.204 & $(0.20)$ \\
\hline France & 0.569 & (1.33) & -0.539 & $(-0.82)$ & 0.281 & $(0.52)$ & $-1.981 * * *$ & $(-4.62)$ & -0.543 & $(-0.27)$ \\
\hline Germany & -0.0530 & $(-0.13)$ & $-1.413^{*}$ & $(-2.28)$ & -0.103 & $(-0.20)$ & -0.237 & $(-0.61)$ & -1.040 & $(-1.07)$ \\
\hline Greece & 0.663 & (1.91) & -0.253 & $(-0.46)$ & 0.536 & $(1.15)$ & -0.384 & $(-1.15)$ & 0.531 & $(0.63)$ \\
\hline Hungary & -0.312 & $(-0.61)$ & 0.325 & $(0.36)$ & -0.971 & $(-1.39)$ & -0.200 & $(-0.39)$ & -0.982 & $(-0.68)$ \\
\hline Ireland & -0.207 & $(-0.47)$ & 0.690 & $(1.02)$ & -0.0103 & $(-0.02)$ & $1.232 * *$ & (3.03) & -0.397 & $(-0.34)$ \\
\hline Israel & $-0.964^{*}$ & $(-2.57)$ & 0.0423 & $(0.07)$ & -0.136 & $(-0.29)$ & 0.600 & $(1.62)$ & 0.224 & $(0.26)$ \\
\hline Italy & -0.790 & $(-0.73)$ & 0.646 & $(0.21)$ & 2.633 & $(1.43)$ & 1.062 & $(0.82)$ & & \\
\hline Latvia & -0.255 & $(-0.67)$ & 0.937 & $(1.55)$ & 0.0787 & $(0.16)$ & -0.0602 & $(-0.16)$ & -1.238 & $(-1.30)$ \\
\hline Lithuania & 0.439 & $(1.07)$ & 0.180 & $(0.28)$ & 0.0539 & $(0.11)$ & 0.283 & $(0.69)$ & 0.812 & $(0.77)$ \\
\hline Malta & -0.114 & $(-0.29)$ & $1.467^{*}$ & $(2.47)$ & -0.481 & $(-0.98)$ & $0.933^{*}$ & $(2.45)$ & 0.294 & $(0.34)$ \\
\hline Netherlands & 0.0449 & $(0.11)$ & -0.725 & $(-1.18)$ & -0.411 & $(-0.83)$ & -0.468 & $(-1.27)$ & 0.560 & $(0.55)$ \\
\hline Norway & 0.375 & $(0.98)$ & -0.858 & $(-1.46)$ & 0.0428 & $(0.09)$ & $0.917^{* *}$ & $(2.60)$ & 0.711 & $(0.73)$ \\
\hline Poland & -0.227 & $(-0.56)$ & 0.667 & $(1.11)$ & -0.0819 & $(-0.17)$ & -0.487 & $(-1.29)$ & 0.392 & $(0.41)$ \\
\hline Portugal & 0.427 & $(1.01)$ & 1.092 & $(1.67)$ & -0.267 & $(-0.50)$ & -0.718 & $(-1.77)$ & 0.324 & $(0.28)$ \\
\hline Romania & -0.0277 & $(-0.06)$ & $2.182^{* *}$ & $(3.07)$ & -0.851 & $(-1.51)$ & 0.167 & $(0.38)$ & 0.779 & $(0.76)$ \\
\hline Russia & -0.398 & $(-0.93)$ & 0.443 & $(0.65)$ & -0.772 & $(-1.38)$ & 0.0534 & $(0.12)$ & -0.513 & $(-0.49)$ \\
\hline Serbia & $-1.074^{*}$ & $(-2.08)$ & 0.755 & $(0.83)$ & $-1.924^{* *}$ & $(-2.79)$ & 0.683 & $(1.31)$ & 2.006 & $(1.12)$ \\
\hline Slovakia & -0.0502 & $(-0.06)$ & -1.716 & $(-1.04)$ & 1.637 & $(1.13)$ & 0.272 & $(0.34)$ & -0.0200 & $(-0.01)$ \\
\hline Slovenia & 0.465 & $(1.32)$ & -0.511 & $(-0.94)$ & 0.455 & $(1.01)$ & $-0.717^{*}$ & $(-2.09)$ & 0.693 & $(0.78)$ \\
\hline Spain & 0.372 & $(0.89)$ & $1.645^{*}$ & $(2.54)$ & -0.0748 & $(-0.14)$ & $-0.828^{*}$ & $(-2.00)$ & -0.563 & $(-0.50)$ \\
\hline Sweden & 0.215 & $(0.58)$ & 0.356 & $(0.63)$ & -0.484 & $(-1.05)$ & 0.529 & $(1.57)$ & -0.0597 & $(-0.07)$ \\
\hline Switzerland & -0.0426 & $(-0.10)$ & -0.574 & $(-0.79)$ & -0.495 & $(-0.84)$ & $-1.807^{* * *}$ & $(-4.23)$ & -1.100 & $(-0.90)$ \\
\hline Turkey & -0.134 & $(-0.33)$ & 0.234 & $(0.39)$ & -0.0351 & $(-0.07)$ & $0.797^{*}$ & $(2.04)$ & -0.424 & $(-0.46)$ \\
\hline United Kingdom & -0.0234 & $(-0.06)$ & -0.218 & $(-0.36)$ & 0.532 & $(1.08)$ & $1.459 * * *$ & (3.98) & 1.405 & $(1.47)$ \\
\hline
\end{tabular}

$t$ statistics in parentheses ${ }^{*} p<0.05,{ }^{* *} p<0.01,{ }^{* * *} p<0.001$ 
Table 13: Country-Specific linear voting model, Eurovision Song Contest including cultural dimensions, continued 3

\begin{tabular}{|c|c|c|c|c|c|c|}
\hline & Order & & Host & & Religion & \\
\hline Austria & 0.0414 & $(1.53)$ & 0.346 & $(0.37)$ & -0.215 & $(-0.46)$ \\
\hline Belgium & -0.0221 & $(-1.01)$ & 0.200 & $(0.27)$ & 0.865 & $(1.62)$ \\
\hline Bulgaria & $-0.0761 *$ & $(-2.41)$ & 0.325 & $(0.30)$ & 1.172 & $(1.23)$ \\
\hline Croatia & -0.0350 & $(-1.69)$ & 0.867 & $(1.26)$ & $0.898^{*}$ & $(2.27)$ \\
\hline Czech Republic & 0.0255 & $(0.59)$ & 3.661 ** & $(2.75)$ & 0.896 & $(1.19)$ \\
\hline Denmark & 0.0318 & $(1.35)$ & 1.078 & $(1.35)$ & 0.692 & $(1.03)$ \\
\hline Estonia & 0.0140 & $(0.70)$ & -0.185 & $(-0.27)$ & 0.677 & $(1.39)$ \\
\hline Finland & 0.0241 & $(0.89)$ & -1.290 & $(-1.36)$ & -0.551 & $(-0.78)$ \\
\hline France & -0.00973 & $(-0.38)$ & -0.0887 & $(-0.11)$ & $1.266^{*}$ & $(2.01)$ \\
\hline Germany & $0.0518^{*}$ & $(2.22)$ & $1.633^{*}$ & $(2.03)$ & 0.498 & $(0.67)$ \\
\hline Greece & -0.00888 & $(-0.43)$ & -0.0382 & $(-0.05)$ & $1.221 *$ & $(1.98)$ \\
\hline Hungary & 0.0485 & $(1.54)$ & -0.783 & $(-0.71)$ & -0.0970 & $(-0.15)$ \\
\hline Ireland & -0.0180 & $(-0.69)$ & $-1.908^{*}$ & $(-2.23)$ & 1.096 & $(1.85)$ \\
\hline Israel & $-0.0577^{* *}$ & $(-2.66)$ & -1.341 & $(-1.76)$ & & \\
\hline Italy & 0.0559 & $(0.68)$ & 1.240 & $(0.49)$ & 0.850 & $(0.46)$ \\
\hline Latvia & 0.0200 & $(0.89)$ & -0.358 & $(-0.46)$ & 0.199 & $(0.26)$ \\
\hline Lithuania & -0.00616 & $(-0.25)$ & -0.173 & $(-0.21)$ & $1.040^{*}$ & $(2.17)$ \\
\hline Malta & -0.0213 & $(-0.94)$ & -1.267 & $(-1.68)$ & -0.360 & $(-0.89)$ \\
\hline Netherlands & 0.0166 & $(0.71)$ & 0.764 & $(0.98)$ & -0.617 & $(-1.25)$ \\
\hline Norway & 0.0131 & $(0.58)$ & 0.440 & $(0.57)$ & 0.622 & $(1.02)$ \\
\hline Poland & $0.0702^{* *}$ & $(2.95)$ & 0.495 & $(0.65)$ & 0.747 & $(1.85)$ \\
\hline Portugal & 0.0173 & $(0.69)$ & -0.817 & $(-0.97)$ & -0.134 & $(-0.21)$ \\
\hline Romania & 0.00143 & $(0.06)$ & 0.155 & $(0.18)$ & $1.856^{*}$ & $(2.44)$ \\
\hline Russia & -0.00523 & $(-0.21)$ & -1.614 & $(-1.84)$ & $1.728^{*}$ & $(2.45)$ \\
\hline Serbia & -0.0134 & $(-0.42)$ & -2.165 & $(-1.95)$ & $2.286^{*}$ & $(2.44)$ \\
\hline Slovakia & 0.0104 & $(0.20)$ & -2.209 & $(-1.26)$ & 0.320 & $(0.37)$ \\
\hline Slovenia & 0.0258 & $(1.23)$ & 0.450 & $(0.65)$ & -0.315 & $(-0.71)$ \\
\hline Spain & $0.0555^{*}$ & $(2.24)$ & -1.439 & $(-1.77)$ & -0.696 & $(-0.98)$ \\
\hline Sweden & 0.0152 & $(0.72)$ & 1.276 & $(1.68)$ & 1.113 & $(1.86)$ \\
\hline Switzerland & 0.0339 & $(1.28)$ & 0.587 & $(0.65)$ & 0.352 & $(0.54)$ \\
\hline Turkey & $-0.0458^{*}$ & $(-1.97)$ & 1.320 & $(1.66)$ & & \\
\hline United Kingdom & 0.0315 & $(1.36)$ & -1.301 & $(-1.65)$ & 0.00888 & $(0.02)$ \\
\hline
\end{tabular}

$t$ statistics in parentheses, ${ }^{*} p<0.05,{ }^{* *} p<0.01,{ }^{* * *} p<0.001$ 
Table 14: Country-Specific linear voting model, Eurovision Song Contest including cultural dimensions, continued 4

\begin{tabular}{|c|c|c|c|c|c|c|c|c|c|c|c|}
\hline & PDI & & IDV & & MAS & & UAI & & cons & & $\mathrm{N}$ \\
\hline Austria & -0.00386 & $(-0.37)$ & 0.0534 & $(1.83)$ & $-0.0258^{*}$ & $(-2.12)$ & $-0.0435^{*}$ & $(-2.11)$ & $3.565^{*}$ & $(2.24)$ & 187 \\
\hline Belgium & $0.0754^{* * *}$ & $(-4.60)$ & 0.0151 & $(0.91)$ & 0.00442 & $(0.30)$ & $0.0652^{* * *}$ & $(4.27)$ & $-4.005^{*}$ & $(-2.59)$ & 278 \\
\hline Bulgaria & -0.0282 & $(-1.37)$ & -0.0100 & $(-0.39)$ & 0.0345 & (1.19) & 0.00672 & $(0.33)$ & -1.132 & $(-0.86)$ & 160 \\
\hline \multirow{2}{*}{$\begin{array}{l}\text { Croatia } \\
\text { Czech Re- } \\
\text { public }\end{array}$} & -0.00899 & $(-0.68)$ & -0.0152 & $(-0.98)$ & 0.00705 & $(0.33)$ & 0.00126 & $(0.09)$ & -0.415 & $(-0.52)$ & 296 \\
\hline & 0.0326 & $(1.19)$ & 0.0221 & $(0.60)$ & -0.0141 & $(-0.56)$ & $0.0567 *$ & $(2.09)$ & $-4.471^{*}$ & $(-2.11)$ & 53 \\
\hline Denmark & 0.0159 & $(0.96)$ & $-0.0645^{* * *}$ & $(-3.48)$ & $-0.0337 * *$ & $(-2.62)$ & $-0.0329 *$ & $(-2.36)$ & 1.035 & $(1.03)$ & 250 \\
\hline Estonia & $-0.0409 * *$ & $(-2.73)$ & $-0.0620^{* * *}$ & $(-3.76)$ & -0.0150 & $(-1.23)$ & 0.0146 & $(1.00)$ & $2.564^{* *}$ & $(3.05)$ & 297 \\
\hline Finland & -0.0250 & $(-1.31)$ & -0.0282 & $(-1.16)$ & -0.0164 & $(-1.08)$ & -0.0288 & $(-1.35)$ & $3.842^{* * *}$ & $(3.34)$ & 235 \\
\hline France & -0.00494 & $(-0.30)$ & 0.0348 & $(1.61)$ & -0.0369 & $(-1.63)$ & 0.0355 & $(1.90)$ & -2.902 & $(-1.49)$ & 291 \\
\hline Germany & -0.00820 & $(-0.51)$ & $0.0527^{*}$ & $(2.46)$ & $-0.0330 *$ & $(-2.16)$ & -0.0107 & $(-0.59)$ & -0.829 & $(-0.90)$ & 291 \\
\hline Greece & -0.0285 & $(-1.56)$ & 0.00974 & $(0.56)$ & $-0.0257^{*}$ & $(-2.16)$ & 0.00232 & $(0.16)$ & 0.940 & $(1.37)$ & 252 \\
\hline Hungary & 0.00886 & $(0.34)$ & 0.0281 & $(1.22)$ & 0.00277 & $(0.20)$ & 0.0280 & (1.59) & -0.0380 & $(-0.02)$ & 144 \\
\hline Ireland & 0.0199 & $(1.14)$ & $-0.0854^{* * *}$ & $(-3.45)$ & $0.0508^{* * *}$ & $(3.38)$ & 0.00467 & $(0.22)$ & -2.113 & $(-1.44)$ & 274 \\
\hline Israel & $0.0521 * * *$ & $(4.32)$ & -0.0377 & $(-1.79)$ & 0.00387 & $(0.21)$ & $0.0379 *$ & $(2.47)$ & $-3.102^{* *}$ & $(-2.98)$ & 282 \\
\hline Italy & 0.0433 & $(0.75)$ & 0.0133 & $(0.23)$ & -0.0125 & $(-0.35)$ & -0.0346 & $(-0.78)$ & 0.277 & $(0.07)$ & 53 \\
\hline Latvia & 0.0110 & $(0.56)$ & $-0.0806^{* * *}$ & $(-5.02)$ & 0.000882 & $(0.08)$ & 0.0000341 & $(0.00)$ & 0.441 & $(0.32)$ & 256 \\
\hline Lithuania & $-0.0380 *$ & $(-2.04)$ & -0.0130 & $(-0.58)$ & $-0.0277^{*}$ & $(-2.23)$ & -0.0157 & $(-0.84)$ & 1.010 & $(1.27)$ & 232 \\
\hline Malta & -0.0183 & $(-1.12)$ & 0.0199 & $(1.02)$ & 0.0159 & $(0.78)$ & $0.0254^{*}$ & $(1.98)$ & -0.137 & $(-0.13)$ & 295 \\
\hline Netherlands & $-0.0463^{* *}$ & $(-2.68)$ & 0.0301 & $(1.68)$ & 0.0123 & $(1.13)$ & -0.00938 & $(-0.57)$ & 0.0772 & $(0.10)$ & 279 \\
\hline Norway & 0.0205 & $(1.21)$ & $-0.0392^{*}$ & $(-2.10)$ & $-0.0203^{*}$ & $(-2.06)$ & -0.00563 & $(-0.32)$ & 0.296 & $(0.31)$ & 273 \\
\hline Poland & 0.0288 & $(1.78)$ & -0.0359 & $(-1.90)$ & 0.00511 & $(0.42)$ & -0.00635 & $(-0.53)$ & -0.179 & $(-0.17)$ & 222 \\
\hline Portugal & $0.0666^{* * *}$ & $(3.64)$ & 0.0143 & $(0.85)$ & 0.00345 & $(0.20)$ & -0.0249 & $(-1.70)$ & 0.965 & $(0.58)$ & 239 \\
\hline Romania & 0.0149 & $(0.99)$ & -0.0247 & $(-1.28)$ & -0.0200 & $(-0.91)$ & 0.00390 & $(0.23)$ & 0.937 & $(1.01)$ & 252 \\
\hline Russia & 0.0269 & $(1.59)$ & $0.0608^{* *}$ & $(2.64)$ & -0.0459 & $(-1.92)$ & $-0.0389 *$ & $(-2.51)$ & -0.838 & $(-0.74)$ & 250 \\
\hline Serbia & 0.00920 & $(0.40)$ & 0.000155 & $(0.01)$ & 0.0422 & $(1.26)$ & -0.0332 & $(-1.38)$ & -0.147 & $(-0.10)$ & 119 \\
\hline Slovakia & 0.0253 & $(1.09)$ & -0.0303 & $(-0.65)$ & 0.0114 & $(0.53)$ & -0.0120 & $(-0.36)$ & -1.442 & $(-0.46)$ & 92 \\
\hline Slovenia & 0.0200 & $(1.47)$ & -0.0106 & $(-0.69)$ & $-0.0300 * *$ & $(-2.64)$ & 0.0170 & $(1.36)$ & $2.443^{* *}$ & $(3.01)$ & 279 \\
\hline Spain & $0.0538^{* *}$ & $(3.24)$ & 0.0143 & $(0.47)$ & 0.0237 & $(1.27)$ & $-0.0320^{*}$ & $(-2.14)$ & 1.330 & $(0.63)$ & 291 \\
\hline Sweden & 0.0117 & $(0.70)$ & -0.00805 & $(-0.47)$ & -0.00519 & $(-0.56)$ & -0.0152 & $(-1.29)$ & -0.125 & $(-0.13)$ & 292 \\
\hline Switzerland & $-0.0410^{*}$ & $(-2.29)$ & $0.0888^{* * *}$ & (3.39) & -0.0177 & $(-1.24)$ & -0.0179 & $(-0.96)$ & 1.614 & $(0.99)$ & 238 \\
\hline Turkey & 0.0138 & $(0.83)$ & -0.00531 & $(-0.30)$ & -0.00656 & $(-0.38)$ & -0.0234 & $(-1.26)$ & -1.170 & $(-1.20)$ & 274 \\
\hline $\begin{array}{l}\text { United King- } \\
\text { dom }\end{array}$ & $0.0589 * * *$ & $(-3.59)$ & -0.00779 & $(-0.44)$ & 0.00875 & $(0.69)$ & 0.0326 & (1.87) & -1.600 & $(-1.47)$ & 291 \\
\hline
\end{tabular}

$t$ statistics in parentheses, ${ }^{*} p<0.05,{ }^{* *} p<0.01,{ }^{* * *} p<0.001$ 
Table 15: Linear Voting Model, Bundesvision Song Contest

\begin{tabular}{|c|c|c|}
\hline & $\begin{array}{c}(1) \\
\text { Model } \\
\end{array}$ & $\begin{array}{c}(2) \\
\text { Model } \\
\end{array}$ \\
\hline Neighb $b_{A B}$ & $\begin{array}{l}0.563^{* * *} \\
(3.55)\end{array}$ & $\begin{array}{c}0.609^{* * *} \\
(3.84)\end{array}$ \\
\hline Length_CB $B_{A B}$ & $\begin{array}{c}0.000108 \\
(0.23)\end{array}$ & $\begin{array}{c}0.0000931 \\
(0.19)\end{array}$ \\
\hline Capital_Dis & $\begin{array}{c}-0.00208^{* * *} \\
(-6.44)\end{array}$ & $\begin{array}{c}-0.00203^{* * *} \\
(-6.28)\end{array}$ \\
\hline FormerGDR ${ }_{B}$ & $\begin{array}{l}-0.134 \\
(-1.66)\end{array}$ & $\begin{array}{l}-0.0872 \\
(-1.06)\end{array}$ \\
\hline Home_Bias & $\begin{array}{l}7.925^{* * *} \\
(42.88)\end{array}$ & $\begin{array}{l}8.093^{* * *} \\
(37.78)\end{array}$ \\
\hline Male_solo ${ }_{B t}$ & $\begin{array}{c}-0.0344 \\
(-0.24)\end{array}$ & $\begin{array}{c}-0.0505 \\
(-0.35)\end{array}$ \\
\hline Duet $_{B t}$ & $\begin{array}{c}-0.0436 \\
(-0.47)\end{array}$ & $\begin{array}{c}-0.0596 \\
(-0.64)\end{array}$ \\
\hline Group $_{B t}$ & $\begin{array}{c}-0.00126 \\
(-0.01)\end{array}$ & $\begin{array}{c}-0.00768 \\
(-0.06)\end{array}$ \\
\hline Order $_{B t}$ & $\begin{array}{c}-0.000864 \\
(-0.11)\end{array}$ & $\begin{array}{c}-0.00172 \\
(-0.22)\end{array}$ \\
\hline Host $_{B t}$ & $\begin{array}{c}-0.0151 \\
(-0.10)\end{array}$ & $\begin{array}{c}-0.0706 \\
(-0.46)\end{array}$ \\
\hline Religion $_{A B}$ & $\begin{array}{l}0.192^{*} \\
(2.12)\end{array}$ & $\begin{array}{l}0.123 \\
(1.35)\end{array}$ \\
\hline Openness $A B$ & & $\begin{array}{l}0.209 \\
(0.64)\end{array}$ \\
\hline Agreeableness $A B$ & & $\begin{array}{c}-1.910^{* *} \\
(-3.20)\end{array}$ \\
\hline Extraversion $_{A B}$ & & $\begin{array}{l}1.446^{*} \\
(2.19)\end{array}$ \\
\hline Neuroticism $_{A B}$ & & $\begin{array}{c}-1.138^{* * *} \\
(-3.32)\end{array}$ \\
\hline Conscientiousness $\mathrm{S}_{\mathrm{AB}}$ & & $\begin{array}{c}1.913^{* * *} \\
(4.15)\end{array}$ \\
\hline _cons & $\begin{array}{c}0.0194 \\
(0.09)\end{array}$ & $\begin{array}{c}-0.0739 \\
(-0.32)\end{array}$ \\
\hline$N$ & 2304 & 2304 \\
\hline
\end{tabular}

$t$ statistics in parentheses, ${ }^{*} p<0.05,{ }^{* *} p<0.01,{ }^{* * *} p<0.001$ 
Table 16: Country-Specific linear voting model, Bundesvision Song Contest, 1

\begin{tabular}{lllllll}
\hline Country & Neighb & & Length_CB & \multicolumn{3}{l}{ Capital_Dis } \\
\hline Brandenburg & 1.405 & $(0.81)$ & -0.00554 & $(-1.14)$ & -0.00283 & $(-1.81)$ \\
Berlin & & & 0.00569 & $(1.88)$ & -0.000116 & $(-0.07)$ \\
Baden-Wuerttemberg & 0.0974 & $(0.16)$ & 0.00115 & $(1.22)$ & -0.00188 & $(-1.23)$ \\
Bavaria & 0.146 & $(0.30)$ & $0.00199^{*}$ & $(2.50)$ & 0.000230 & $(0.15)$ \\
Bremen & & & 0.00730 & $(1.35)$ & $-0.00305^{*}$ & $(-2.29)$ \\
Hesse & 1.218 & $(0.99)$ & -0.00301 & $(-0.60)$ & -0.00117 & $(-0.79)$ \\
Hamburg & $-3.478^{*}$ & $(-2.29)$ & $0.0469 * *$ & $(3.22)$ & $-0.00469 * * *$ & $(-3.94)$ \\
Mecklenbur-Western & 0.365 & $(0.50)$ & 0.00105 & $(0.40)$ & -0.000759 & $(-0.66)$ \\
Pomerania & & & & & & \\
Lower Saxony & $-1.624 *$ & $(-2.95)$ & $0.00291^{*}$ & $(2.38)$ & $-0.00800 * * *$ & $(-4.06)$ \\
North Rhine- & -0.147 & $(-0.17)$ & -0.0000691 & $(-0.03)$ & 0.00185 & $(1.17)$ \\
Westphalia & & & & & & $(-0.27)$ \\
Rhineland-Palatinate & $3.120^{* *}$ & $(3.24)$ & -0.00467 & $(-1.44)$ & -0.000472 & $(-0.59)$ \\
Saxony-Anhalt & $-3.364 *$ & $(-2.03)$ & 0.00896 & $(1.71)$ & -0.00144 & $(-4.25)$ \\
Schleswig-Holstein & 2.338 & $(0.49)$ & -0.0142 & $(-0.38)$ & $-0.00483 * * *$ & $(-0.90)$ \\
Saarland & & & $0.00955^{* *}$ & $(2.74)$ & -0.00120 & $(-2.04)$ \\
Saxony & -0.216 & $(-0.27)$ & -0.00364 & $(-0.81)$ & $-0.00572 *$ & $(-0.28)$ \\
Thuringia & -0.250 & $(-0.24)$ & 0.00215 & $(0.68)$ & -0.000993 & \\
\hline
\end{tabular}

$t$ statistics in parentheses, ${ }^{*} p<0.05,{ }^{* *} p<0.01,{ }^{* * *} p<0.001$

Table 17: Country-Specific linear voting model, Bundesvision Song Contest, continued 2

\begin{tabular}{|c|c|c|c|c|}
\hline \multirow{2}{*}{$\begin{array}{l}\text { Country }_{A} \\
\text { Branden-burg }\end{array}$} & \multirow{2}{*}{$\begin{array}{c}\text { FormerGDR } \\
0.00905\end{array}$} & \multicolumn{3}{|c|}{ Home_Bias } \\
\hline & & $(0.01)$ & $6.666^{* * *}$ & $(8.00)$ \\
\hline Berlin & 1.185 & $(1.68)$ & $4.900 * * *$ & $(5.06)$ \\
\hline Baden-Wuerttemberg & -0.446 & $(-1.31)$ & $8.012^{* * *}$ & (10.67) \\
\hline Bavaria & 0.0657 & $(0.25)$ & $11.22 * * *$ & (14.83) \\
\hline Bremen & $-1.054 * *$ & $(-2.85)$ & $9.145^{* * *}$ & (11.77) \\
\hline Hesse & -0.277 & $(-0.78)$ & $9.154^{* * *}$ & $(10.40)$ \\
\hline Hamburg & 1.339 & $(1.85)$ & $8.805^{* * *}$ & $(9.44)$ \\
\hline $\begin{array}{l}\text { Mecklenburg- } \\
\text { Western Pomerania }\end{array}$ & 0.0192 & $(0.04)$ & $10.39 * * *$ & $(17.70)$ \\
\hline Lower Saxony & $-1.094 * *$ & $(-2.99)$ & $2.102 *$ & $(2.18)$ \\
\hline $\begin{array}{l}\text { North Rhine- } \\
\text { Westphalia }\end{array}$ & $-1.328 * * *$ & $(-4.05)$ & $7.302 * * *$ & $(9.51)$ \\
\hline Rhineland-Palatinate & -0.454 & $(-1.37)$ & $11.10 * * *$ & (11.57) \\
\hline Saxony-Anhalt & $2.453 * * *$ & $(3.47)$ & $6.986^{* * *}$ & $(7.51)$ \\
\hline Schleswig-Holstein & $-1.862 * * *$ & $(-5.12)$ & $6.558 * * *$ & $(8.77)$ \\
\hline Saarland & -0.286 & $(-0.75)$ & $10.12 * * *$ & $(13.05)$ \\
\hline Saxony & $2.256^{* *}$ & $(2.96)$ & $4.036^{* * *}$ & (3.59) \\
\hline Thuringia & $1.391 *$ & $(2.51)$ & $8.053 * * *$ & $(7.70)$ \\
\hline
\end{tabular}

$t$ statistics in parentheses, ${ }^{*} p<0.05,{ }^{* *} p<0.01,{ }^{* \star *} p<0.001$ 
Table 18: Country-Specific linear voting model, Bundesvision Song Contest, continued 3

\begin{tabular}{|c|c|c|c|c|c|c|c|c|}
\hline Country $_{A}$ & Male_solo & & Duet & & Group & & Order & \\
\hline Brandenburg & -0.969 & $(-1.72)$ & -0.347 & $(-1.00)$ & 0.138 & $(0.27)$ & 0.00970 & $(0.32)$ \\
\hline Berlin & -0.155 & $(-0.26)$ & -0.441 & $(-1.17)$ & 0.0223 & $(0.04)$ & 0.0334 & $(1.00)$ \\
\hline $\begin{array}{l}\text { Baden- } \\
\text { Wuerttemberg }\end{array}$ & 0.375 & $(0.73)$ & 0.135 & $(0.41)$ & -0.470 & $(-0.97)$ & -0.0166 & $(-0.57)$ \\
\hline Bavaria & 0.445 & $(1.11)$ & 0.117 & $(0.45)$ & 0.0277 & $(0.07)$ & 0.0257 & $(1.14)$ \\
\hline Bremen & $-1.464^{*}$ & $(-2.46)$ & 0.362 & $(0.97)$ & $-1.393^{*}$ & $(-2.50)$ & $\begin{array}{c}- \\
0.000312\end{array}$ & $(-0.01)$ \\
\hline Hesse & 0.341 & $(0.64)$ & 0.292 & $(0.84)$ & 0.211 & $(0.42)$ & 0.0251 & $(0.84)$ \\
\hline Hamburg & 0.965 & (1.54) & -0.210 & $(-0.54)$ & 0.552 & $(0.95)$ & 0.0154 & $(0.45)$ \\
\hline $\begin{array}{l}\text { Mecklenburg- } \\
\text { Western Pom- } \\
\text { erania }\end{array}$ & 0.169 & $(0.37)$ & -0.520 & $(-1.83)$ & 0.448 & $(1.05)$ & 0.0288 & $(1.16)$ \\
\hline Lower Saxony & 0.241 & $(0.45)$ & -0.0537 & $(-0.16)$ & -0.191 & $(-0.39)$ & 0.00928 & $(0.32)$ \\
\hline $\begin{array}{l}\text { North Rhine- } \\
\text { Westphalia }\end{array}$ & 0.261 & $(0.55)$ & 0.111 & $(0.36)$ & 0.231 & $(0.51)$ & 0.0176 & $(0.66)$ \\
\hline $\begin{array}{l}\text { Rhineland- } \\
\text { Palatinate }\end{array}$ & 0.588 & $(1.14)$ & 0.332 & $(1.00)$ & 0.163 & $(0.33)$ & 0.00140 & $(0.05)$ \\
\hline Saxony-Anhalt & -0.206 & $(-0.31)$ & 0.162 & $(0.40)$ & 0.309 & $(0.51)$ & 0.0363 & $(1.02)$ \\
\hline $\begin{array}{l}\text { Schleswig- } \\
\text { Holstein }\end{array}$ & 0.0584 & $(0.11)$ & 0.411 & $(1.22)$ & -0.527 & $(-1.06)$ & 0.0157 & $(0.54)$ \\
\hline Saarland & 0.00624 & $(0.01)$ & 0.213 & $(0.54)$ & 0.319 & $(0.56)$ & -0.0423 & $(-1.26)$ \\
\hline Saxony & -0.793 & $(-1.22)$ & 0.0206 & $(0.05)$ & 0.180 & $(0.30)$ & -0.0303 & $(-0.84)$ \\
\hline Thuringia & 0.580 & $(1.00)$ & -0.404 & $(-1.12)$ & 0.893 & $(1.67)$ & -0.0486 & $(-1.56)$ \\
\hline
\end{tabular}

$t$ statistics in parentheses, ${ }^{*} p<0.05,{ }^{* *} p<0.01,{ }^{* * *} p<0.001$

Table 19: Country-Specific linear voting model, Bundesvision Song Contest, continued 4

\begin{tabular}{llllllll}
\hline Country & Host & & Religion & & cons & & N \\
\hline Brandenburg & 1.045 & $(1.80)$ & 0.835 & $(1.38)$ & 0.188 & $(0.21)$ & 144 \\
Berlin & 0.761 & $(1.18)$ & 0.334 & $(0.47)$ & -1.063 & $(-1.09)$ & 144 \\
Baden- & 0.00217 & $(0.00)$ & -0.479 & $(-1.02)$ & 0.692 & $(0.71)$ & 144 \\
Wuerttemberg & & & & & & & \\
Bavaria & -0.0948 & $(-0.22)$ & 0.149 & $(0.38)$ & -1.461 & $(-1.45)$ & 144 \\
Bremen & $-1.387^{*}$ & $(-2.26)$ & -0.464 & $(-0.95)$ & $1.955^{*}$ & $(2.38)$ & 144 \\
Hesse & -0.329 & $(-0.59)$ & -0.651 & $(-1.56)$ & -0.676 & $(-0.91)$ & 144 \\
Hamburg & -0.336 & $(-0.50)$ & $-2.157^{* *}$ & $(-3.02)$ & 0.530 & $(0.68)$ & 144 \\
Mecklenburg- & 0.690 & $(1.46)$ & 0.525 & $(1.00)$ & -1.259 & $(-1.89)$ & 144 \\
Western Pomerania & & & & & & \\
Lower Saxony & -0.445 & $(-0.80)$ & $1.651^{* * *}$ & $(3.55)$ & $2.257^{*}$ & $(2.42)$ & 144 \\
North Rhine- & 0.930 & $(1.82)$ & $-0.716^{*}$ & $(-2.21)$ & -0.829 & $(-1.05)$ & 144 \\
Westphalia & & & & & & & 144 \\
Rhineland- & -0.654 & $(-1.18)$ & -0.412 & $(-0.99)$ & -1.123 & $(-1.25)$ & 144 \\
$\begin{array}{l}\text { Palatinate } \\
\text { Saxony-Anhalt }\end{array}$ & 0.513 & $(0.76)$ & -0.685 & $(-1.00)$ & -0.953 & $(-0.89)$ & 144 \\
Schleswig-Holstein & -0.502 & $(-0.91)$ & $-1.379 * *$ & $(-3.26)$ & $2.234^{* *}$ & $(2.69)$ & 144 \\
Saarland & -0.199 & $(-0.31)$ & 0.300 & $(0.61)$ & -0.198 & $(-0.23)$ & 144 \\
Saxony & 0.268 & $(0.39)$ & -0.959 & $(-1.44)$ & 1.834 & $(1.29)$ & 144 \\
Thuringia & 0.840 & $(1.41)$ & -0.635 & $(-1.30)$ & -0.798 & $(-0.65)$ & 144 \\
\hline
\end{tabular}

$t$ statistics in parentheses, ${ }^{*} p<0.05,{ }^{* *} p<0.01,{ }^{* * *} p<0.001$ 
Table 20: Country-Specific linear voting model, Bundesvision Song Contest, including Big 5, 1

\begin{tabular}{lllllll}
\hline Country & Neighb & & Length_CB & \multicolumn{3}{c}{ Capital_Dis } \\
\hline Brandenburg & -0.169 & $(-0.08)$ & -0.00196 & $(-0.35)$ & -0.00219 & $(-0.85)$ \\
Berlin & & & 0.00622 & $(1.75)$ & -0.0000139 & $(-0.01)$ \\
Baden-Wuerttemberg & -0.387 & $(-0.47)$ & 0.00107 & $(1.08)$ & -0.00335 & $(-0.80)$ \\
Bavaria & 0.391 & $(0.74)$ & $0.00232^{*}$ & $(2.23)$ & 0.00240 & $(0.97)$ \\
Bremen & & & $0.0126^{*}$ & $(2.08)$ & -0.00267 & $(-1.37)$ \\
Hesse & 1.265 & $(0.84)$ & -0.00162 & $(-0.29)$ & -0.000583 & $(-0.35)$ \\
Hamburg & -2.208 & $(-1.10)$ & 0.0355 & $(1.69)$ & $-0.00459^{*}$ & $(-2.49)$ \\
Mecklenburg-Western & 0.312 & $(0.37)$ & 0.00147 & $(0.51)$ & 0.00128 & $(0.58)$ \\
Pomerania & & & & & & \\
Lower Saxony & $3.286^{* * *}$ & $(-4.79)$ & $0.00469 * *$ & $(3.20)$ & $-0.00720^{* *}$ & $(-3.30)$ \\
North Rhine-Westphalia & -0.120 & $(-0.09)$ & -0.00160 & $(-0.69)$ & -0.000574 & $(-0.27)$ \\
Rhineland-Palatinate & $\mathbf{3 . 4 1 3 *}$ & $(1.99)$ & -0.00600 & $(-1.02)$ & 0.000626 & $(0.28)$ \\
Saxony-Anhalt & -2.023 & $(-1.09)$ & 0.00139 & $(0.23)$ & $-0.00708^{*}$ & $(-2.21)$ \\
Schleswig-Holstein & 0.528 & $(0.09)$ & -0.00220 & $(-0.05)$ & $-0.00477^{*}$ & $(-2.14)$ \\
Saarland & & & $0.0102 *$ & $(2.45)$ & -0.00145 & $(-0.60)$ \\
Saxony & -0.613 & $(-0.81)$ & -0.00825 & $(-1.66)$ & $-0.00785^{*}$ & $(-2.28)$ \\
Thuringia & -0.528 & $(-0.39)$ & 0.00119 & $(0.32)$ & 0.000170 & $(0.04)$ \\
\hline
\end{tabular}

$t$ statistics in parentheses, ${ }^{*} p<0.05,{ }^{* *} p<0.01,{ }^{* * *} p<0.001$

Table 21: Country-Specific linear voting model, Bundesvision Song Contest, including Big 5, continued 2

\begin{tabular}{lllll}
\hline CountryA & FormerGDR & \multicolumn{3}{l}{ Home_Bias } \\
\hline Branden-burg & 0.154 & $(0.07)$ & $6.141^{* * *}$ & $(5.66)$ \\
Berlin & 1.362 & $(1.26)$ & $5.234^{* * *}$ & $(3.89)$ \\
Baden-Wuerttemberg & -1.030 & $(-1.96)$ & $7.458^{* * *}$ & $(6.13)$ \\
Bavaria & 0.250 & $(0.73)$ & $12.16^{* * *}$ & $(11.24)$ \\
Bremen & $-2.495^{*}$ & $(-2.12)$ & $10.33^{* * *}$ & $(7.53)$ \\
Hesse & 0.344 & $(0.64)$ & $9.956^{* * *}$ & $(5.98)$ \\
Hamburg & 0.774 & $(0.54)$ & $9.299^{* * *}$ & $(6.84)$ \\
Mecklenburg-Western Po- & -0.698 & $(-0.88)$ & $9.772^{* * *}$ & $(12.85)$ \\
merania & & & & \\
Lower Saxony & $-0.956^{*}$ & $(-2.59)$ & 1.569 & $(1.02)$ \\
North Rhine-Westphalia & $-1.338^{*}$ & $(-2.44)$ & $6.616^{* * *}$ & $(4.50)$ \\
Rhineland-Palatinate & -0.670 & $(-1.33)$ & $11.19^{* * *}$ & $(10.38)$ \\
Saxony-Anhalt & 0.609 & $(0.47)$ & $3.948^{* *}$ & $(3.16)$ \\
Schleswig-Holstein & -0.00625 & $(-0.01)$ & 2.270 & $(1.22)$ \\
Saarland & -0.119 & $(-0.14)$ & $10.21^{* * *}$ & $(7.55)$ \\
Saxony & -0.633 & $(-0.63)$ & 1.142 & $(0.81)$ \\
Thuringia & $3.577^{*}$ & $(2.10)$ & $6.928^{* * *}$ & $(4.71)$ \\
\hline
\end{tabular}

$t$ statistics in parentheses, ${ }^{*} p<0.05,{ }^{* *} p<0.01,{ }^{* * *} p<0.001$ 
Table 22: Country-Specific linear voting model, Bundesvision Song Contest, including Big 5, continued 3

\begin{tabular}{|c|c|c|c|c|c|c|c|c|}
\hline \multirow{2}{*}{$\begin{array}{l}\text { Country }_{A} \\
\text { Brandenburg }\end{array}$} & \multicolumn{2}{|c|}{ Male_solo } & \multicolumn{2}{|l|}{ Duet } & \multirow{2}{*}{$\begin{array}{c}\text { Group } \\
-0.00108\end{array}$} & \multicolumn{3}{|c|}{ Order } \\
\hline & -1.128 & $(-1.97)$ & -0.463 & $(-1.30)$ & & $(-0.00)$ & 0.00961 & $(0.31)$ \\
\hline Berlin & -0.0785 & $(-0.13)$ & -0.428 & $(-1.09)$ & 0.120 & $(0.21)$ & 0.0276 & $(0.79)$ \\
\hline $\begin{array}{l}\text { Baden- } \\
\text { Wuerttemberg }\end{array}$ & 0.438 & $(0.82)$ & 0.146 & $(0.44)$ & -0.565 & $(-1.14)$ & -0.0182 & $(-0.61)$ \\
\hline Bavaria & 0.226 & $(0.55)$ & 0.138 & $(0.53)$ & -0.157 & $(-0.40)$ & 0.0163 & $(0.70)$ \\
\hline Bremen & $-1.675^{* *}$ & $(-2.75)$ & 0.296 & $(0.79)$ & $-1.447^{*}$ & $(-2.59)$ & 0.00306 & $(0.09)$ \\
\hline Hesse & 0.323 & $(0.58)$ & 0.305 & $(0.87)$ & 0.136 & $(0.26)$ & 0.0123 & $(0.40)$ \\
\hline Hamburg & 0.908 & $(1.42)$ & -0.139 & $(-0.34)$ & 0.477 & $(0.80)$ & 0.0209 & $(0.58)$ \\
\hline $\begin{array}{l}\text { Mecklenburg- } \\
\text { Western Po- } \\
\text { merania }\end{array}$ & 0.0732 & $(0.16)$ & -0.504 & $(-1.73)$ & 0.373 & $(0.87)$ & 0.0443 & $(1.70)$ \\
\hline Lower Saxony & 0.536 & $(1.12)$ & 0.0182 & $(0.06)$ & 0.233 & $(0.52)$ & 0.000202 & $(0.01)$ \\
\hline $\begin{array}{l}\text { North Rhine- } \\
\text { Westphalia } \\
\text { Rhineland- }\end{array}$ & 0.246 & $(0.50)$ & 0.145 & $(0.47)$ & 0.199 & $(0.43)$ & 0.0176 & $(0.66)$ \\
\hline Palatinate & 0.541 & $(1.04)$ & 0.253 & $(0.76)$ & 0.0864 & $(0.18)$ & -0.00632 & $(-0.21)$ \\
\hline Saxony-Anhalt & -0.345 & $(-0.54)$ & -0.0291 & $(-0.07)$ & 0.230 & $(0.39)$ & 0.0611 & $(1.76)$ \\
\hline $\begin{array}{l}\text { Schleswig- } \\
\text { Holstein }\end{array}$ & 0.246 & $(0.47)$ & 0.440 & $(1.35)$ & -0.408 & $(-0.85)$ & 0.0181 & $(0.62)$ \\
\hline Saarland & -0.0903 & $(-0.14)$ & 0.195 & $(0.49)$ & 0.280 & $(0.48)$ & -0.0451 & $(-1.29)$ \\
\hline Saxony & -0.977 & $(-1.59)$ & 0.293 & $(0.75)$ & -0.214 & $(-0.38)$ & -0.0144 & $(-0.42)$ \\
\hline Thuringia & 0.587 & $(0.99)$ & -0.355 & $(-0.98)$ & 0.806 & $(1.49)$ & $-0.0662 *$ & $(-2.02)$ \\
\hline
\end{tabular}

$t$ statistics in parentheses, ${ }^{*} p<0.05,{ }^{* *} p<0.01,{ }^{* * *} p<0.001$

Table 23: Country-Specific linear voting model, Bundesvision Song Contest, including Big 5, continued 4

\begin{tabular}{|c|c|c|c|c|c|c|c|c|}
\hline Country $_{A}$ & Host & & Religion & & Openness & & Agreeabl & \\
\hline Brandenburg & 0.814 & $(1.36)$ & 0.733 & $(0.54)$ & 3.184 & $(0.66)$ & -0.0954 & $(-0.01)$ \\
\hline Berlin & 0.827 & $(1.25)$ & 0.358 & $(0.37)$ & 0.463 & $(0.13)$ & 2.610 & $(0.36)$ \\
\hline $\begin{array}{l}\text { Baden- } \\
\text { Wuerttemberg }\end{array}$ & -0.126 & $(-0.22)$ & -1.376 & $(-1.87)$ & -0.735 & $(-0.14)$ & -3.107 & $(-0.79)$ \\
\hline Bavaria & -0.346 & $(-0.80)$ & 0.135 & $(0.34)$ & 2.218 & $(1.11)$ & $-5.081 *$ & $(-2.22)$ \\
\hline Bremen & $-1.370^{*}$ & $(-2.16)$ & -1.596 & $(-1.72)$ & 3.121 & $(1.53)$ & -14.53 & $(-1.82)$ \\
\hline Hesse & -0.397 & $(-0.69)$ & -0.574 & $(-1.04)$ & 5.118 & $(1.45)$ & -5.491 & $(-1.25)$ \\
\hline Hamburg & -0.298 & $(-0.44)$ & -1.647 & $(-1.52)$ & 1.846 & $(0.67)$ & 4.263 & $(0.92)$ \\
\hline $\begin{array}{l}\text { Mecklenburg- } \\
\text { Western Pomerania }\end{array}$ & 0.663 & $(1.37)$ & 1.176 & $(1.20)$ & -0.786 & $(-0.35)$ & -1.161 & $(-0.31)$ \\
\hline Lower Saxony & -0.329 & $(-0.65)$ & $1.747^{* * *}$ & (3.67) & $-9.128^{* *}$ & $(-2.75)$ & -1.140 & $(-0.29)$ \\
\hline $\begin{array}{l}\text { North Rhine- } \\
\text { Westphalia } \\
\text { Rhineland- }\end{array}$ & 0.775 & $(1.49)$ & $-1.193^{*}$ & $(-2.41)$ & -0.0310 & $(-0.01)$ & -8.782 & $(-1.95)$ \\
\hline Palatinate & -0.900 & $(-1.59)$ & -1.069 & $(-1.62)$ & -0.574 & $(-0.15)$ & -5.033 & $(-1.19)$ \\
\hline Saxony-Anhalt & 0.298 & $(0.45)$ & 0.187 & $(0.17)$ & -7.088 & $(-1.71)$ & -1.658 & $(-0.43)$ \\
\hline Schleswig-Holstein & -0.128 & $(-0.23)$ & -0.455 & $(-0.88)$ & $-4.643^{*}$ & $(-2.14)$ & -5.875 & $(-1.61)$ \\
\hline Saarland & -0.278 & $(-0.41)$ & 0.339 & $(0.53)$ & 0.648 & $(0.16)$ & -1.266 & $(-0.34)$ \\
\hline Saxony & 0.355 & $(0.55)$ & $2.447^{*}$ & $(2.51)$ & $-6.234^{* *}$ & $(-3.01)$ & 14.61 ** & $(2.77)$ \\
\hline Thuringia & 0.647 & (1.05) & -1.171 & $(-1.20)$ & 5.912 & $(1.45)$ & -5.173 & $(-1.33)$ \\
\hline
\end{tabular}

$t$ statistics in parentheses, ${ }^{*} p<0.05,{ }^{* *} p<0.01,{ }^{* * *} p<0.001$ 
Table 24: Country-Specific linear voting model, Bundesvision Song Contest, including Big 5, continued 5

\begin{tabular}{|c|c|c|c|c|c|c|c|c|c|}
\hline Country $_{A}$ & Extrav. & & Neurot. & & Conscie. & & cons & & $\mathbf{N}$ \\
\hline Brandenburg & -4.433 & $(-0.84)$ & -3.402 & $(-1.64)$ & -0.995 & $(-0.21)$ & 0.838 & $(0.47)$ & 144 \\
\hline Berlin & 2.373 & $(0.48)$ & -1.595 & $(-0.50)$ & -0.481 & $(-0.18)$ & -1.458 & $(-0.92)$ & 144 \\
\hline $\begin{array}{l}\text { Baden- } \\
\text { Wuerttemberg }\end{array}$ & -2.601 & $(-0.50)$ & -2.633 & $(-0.52)$ & 3.768 & $(1.12)$ & 2.238 & (1.49) & 144 \\
\hline Bavaria & 0.972 & $(0.48)$ & -1.760 & $(-0.94)$ & 0.215 & $(0.07)$ & -2.148 & $(-1.71)$ & 144 \\
\hline Bremen & 1.511 & $(0.49)$ & 12.495 & (1.58) & $7.901 *$ & $(2.30)$ & 1.965 & $(1.65)$ & 144 \\
\hline Hesse & 6.236 & $(1.21)$ & -0.601 & $(-0.27)$ & -2.760 & $(-0.74)$ & -1.418 & $(-1.00)$ & 144 \\
\hline Hamburg & -3.591 & $(-0.83)$ & -1.044 & $(-0.20)$ & 2.424 & $(0.71)$ & -0.459 & $(-0.25)$ & 144 \\
\hline $\begin{array}{l}\text { Mecklenburg- } \\
\text { Western Pomerania }\end{array}$ & $-6.589 *$ & $(-1.99)$ & 1.961 & $(0.85)$ & -3.960 & $(-1.40)$ & -0.603 & $(-0.72)$ & 144 \\
\hline Lower Saxony & $13.68^{* * *}$ & (3.57) & 4.931 & (1.77) & 2.481 & $(0.86)$ & 2.361 & $(1.70)$ & 144 \\
\hline $\begin{array}{l}\text { North Rhine- } \\
\text { Westphalia }\end{array}$ & 5.765 & $(0.83)$ & -2.460 & $(-1.12)$ & 2.626 & $(0.64)$ & 0.383 & $(0.21)$ & 144 \\
\hline $\begin{array}{l}\text { Rhineland- } \\
\text { Palatinate }\end{array}$ & 3.152 & $(0.73)$ & -5.086 & $(-1.39)$ & 0.0385 & $(0.01)$ & -0.399 & $(-0.38)$ & 144 \\
\hline Saxony-Anhalt & -3.773 & $(-0.96)$ & -2.026 & $(-0.99)$ & -7.165 & $(-1.86)$ & $3.207^{*}$ & $(2.01)$ & 144 \\
\hline Schleswig-Holstein & 5.411 & $(1.68)$ & $-11.57^{* *}$ & $(-3.14)$ & $4.677^{*}$ & $(2.23)$ & $5.465^{* *}$ & (3.25) & 144 \\
\hline Saarland & -0.0613 & $(-0.01)$ & 0.495 & $(0.14)$ & 1.180 & $(0.38)$ & -0.260 & $(-0.21)$ & 144 \\
\hline Saxony & -8.876 & $(-1.69)$ & -0.693 & $(-0.38)$ & $-13.71 * * *$ & $(-3.38)$ & $4.694^{* *}$ & $(2.93)$ & 144 \\
\hline Thuringia & 4.894 & $(1.24)$ & 2.480 & $(0.87)$ & -10.03 & $(-1.07)$ & -1.136 & $(-0.86)$ & 144 \\
\hline
\end{tabular}

$t$ statistics in parentheses, ${ }^{*} p<0.05,{ }^{* *} p<0.01,{ }^{* * *} p<0.001$ 


\section{Diskussionspapiere aus dem Institut für Volkswirtschaftslehre der Technischen Universität IImenau}

Nr. 42 Steinrücken, Torsten; Jaenichen, Sebastian: Wer ist wirklich reich? - Zu Problemen der Wohlfahrtsmessung durch das Bruttoinlandsprodukt, April 2005.

Nr. 43 Steinrücken, Torsten; Jaenichen, Sebastian: Wo bleiben die Subventionssteuern? - Probleme des Beihilfenrechts und ein alternatives Regulierungskonzept, Mai 2005.

Nr. 44 Jaenichen, Sebastian; Steinrücken, Torsten; Schneider, Lutz: Zu den ökonomischen Wirkungen gesetzlicher Feiertage - Eine Diskussion unter besonderer Berücksichtigung der Arbeitszeitpolitik, Juni 2005.

Nr. $45 \quad K u c h i n k e$, Björn A.: Qualitätswettbewerb zwischen deutschen Akutkrankenhäusern unter besonderer Berücksichtigung von DRG und Budgets, Juni 2005.

Nr. 46 Kuchinke, Björn A.; Walterscheid, Heike: Wo steht der Osten? Eine ökonomische Analyse anhand von Wohlfahrts- und Happinessindikatoren, Juni 2005.

Nr. 47 Kuchinke, Björn A.; Schubert, Jens M.: Staatliche Zahlungen an Krankenhäuser: Eine juristische und ökonomische Einschätzung nach Altmark Trans und der Entscheidung der Kommission vom 13.7.2005, August 2005.

Nr. 48 Steinrücken, Torsten; Jaenichen, Sebastian: Überkapazitäten zur Absicherung politischer Risiken und Instrumente finanzwirtschaftlicher Gegensteuerung, November 2005.

Nr. 49 Jaenichen, Sebastian; Steinrücken, Torsten: Opel, Thüringen und das Kaspische Meer, Januar 2006.

Nr. 50 Kallfaß, Hermann H.: Räumlicher Wettbewerb zwischen Allgemeinen Krankenhäusern, Februar 2006.

Nr. 51 Sickmann, Jörn: Airport Slot Allocation, März 2006.

Nr. 52 Kallfaß, Hermann H.; Kuchinke, Björn A.: Die räumliche Marktabgrenzung bei Zusammenschlüssen von Krankenhäusern in den USA und in Deutschland: Eine wettbewerbsökonomische Analyse, April 2006.

Nr. 53 Bamberger, Eva; Bielig, Andreas: Mehr Beschäftigung mittels weniger Kündigungsschutz? Ökonomische Analyse der Vereinbarungen des Koalitionsvertrages vom 11. 11. 2005, Juni 2006. 
Nr. 54 Jaenichen, Sebastian; Steinrücken, Torsten: Zur Ökonomik von Steuergeschenken - Der Zeitverlauf als Erklärungsansatz für die effektive steuerliche Belastung, Dezember 2006.

Nr. 55 Jaenichen, Sebastian; Steinrücken, Torsten: Wirkt eine Preisregulierung nur auf den Preis? Anmerkungen zu den Wirkungen einer Preisregulierung auf das Werbevolumen, Mai 2007.

Nr. 56 Kuchinke, B. A.; Sauerland, D.; Wübker, A.: Determinanten der Wartezeit auf einen Behandlungstermin in deutschen Krankenhäusern - Ergebnisse einer Auswertung neuer Daten, Februar 2008.

Nr. 57 Wegehenkel, Lothar; Walterscheid, Heike: Rechtsstruktur und Evolution von Wirtschaftssystemen - Pfadabhängigkeit in Richtung Zentralisierung?, Februar 2008.

Nr. 58 Steinrücken, Torsten; Jaenichen, Sebastian: Regulierung und Wohlfahrt in einem Modell mit zwei Aktionsparametern, März 2008.

Nr. 59 Lehnert, Ninja M.: Externe Kosten des Luftverkehrs - Ein Überblick über den aktuellen Stand der Diskussion, April 2008.

Nr. 60 Walterscheid, Heike: Reformbedarf etablierter Demokratien im Kontext dezentralisierter Gesellschaftssysteme - Grundlegende Hindernisse bei Steuersystemreformen", April 2010.

Nr. 61 Walterscheid, Heike; Wegehenkel, Lothar: Kostenstruktur, Zahlungsbereitschaft und das Angebot von Mediengütern auf Medienmärkten, Juni 2008.

Nr. 62 Walterscheid, Heike; Wegehenkel, Lothar: Wohlstand der Nationen und handlungsrechtliche Struktur eines Gesellschaftssystems, September 2008.

Nr. 63 Dewenter, Ralf; Haucap, Justus; Wenzel, Tobias: Indirect Network Effects with Two Salop Circles: The Example oft the Music Industry, Juni 2009.

Nr. 64 Dewenter, Ralf; Jaschinski, Thomas; Wiese, Nadine: Wettbewerbliche Auswirkungen eines nichtneutralen Internets, Juli 2009.

Nr. 65 Dewenter, Ralf; Haucap, Justus; Kuchinke, Björn A.: Das Glück und Unglück von Studierenden aus Ost- und Westdeutschland: Ergebnisse einer Befragung in Ilmenau, Bochum und Hamburg, Oktober 2009.

Nr. 66 Kuchinke, Björn A.; Zerth, Jürgen; Wiese, Nadine: Spatial Competition between Health Care Providers: Effects of Standardization, Oktober 2009. 
Nr. 67 Itzenplitz, Anja; Seifferth-Schmidt, Nicole: Warum Klimakonferenzen scheitern, aber dennoch zum Wohl des Weltklimas kooperiert wird, Juli 2010.

Nr. 68 Kallfaß, Hermann H.: Die Aufmerksamkeit für, die Nutzung der und die Werbung in Medien in Deutschland, November 2010.

Nr. 69 Budzinski, Oliver: Empirische Ex-Post Evaluation von wettbewerbspolitischen Entscheidungen: Methodische Anmerkungen, Januar 2012.

Nr. 70 Budzinski, Oliver: The Institutional Framework for Doing Sports Business: Principles of EU Competition Policy in Sports Markets, January 2012.

Nr. 71 Budzinski, Oliver; Monostori, Katalin: Intellectual Property Rights and the WTO, April 2012.

Nr. 72 Budzinski, Oliver: International Antitrust Institutions, Juli 2012.

Nr. 73 Lindstädt, Nadine; Budzinski, Oliver: Newspaper vs. Online Advertising Is There a Niche for Newspapers in Modern Advertising Markets?

Nr. 74 Budzinski, Oliver; Lindstädt, Nadine: Newspaper and Internet Display Advertising - Co-Existence or Substitution?, Juli 2012b.

Nr. 75 Budzinski, Oliver: Impact Evaluation of Merger Control Decisions, August 2012.

Nr. 76 Budzinski, Oliver; Kuchinke, Björn A.: Deal or No Deal? Consensual Arrangements as an Instrument of European Competition Policy, August 2012.

Nr. 77 Pawlowski, Tim, Budzinski, Oliver: The (Monetary) Value of Competitive Balance for Sport Consumers, Oktober 2012.

Nr. 78 Budzinski, Oliver: Würde eine unabhängige europäische Wettbewerbsbehörde eine bessere Wettbewerbspolitik machen?, November 2012.

Nr. 79 Budzinski, Oliver; Monostori, Katalin; Pannicke, Julia: Der Schutz geistiger Eigentumsrechte in der Welthandelsorganisation - Urheberrechte im TRIPS Abkommen und die digitale Herausforderung, November 2012.

Nr. 80 Beigi, Maryam H. A.; Budzinski, Oliver: On the Use of Event Studies to Evaluate Economic Policy Decisions: A Note of Caution, Dezember 2012.

Nr. 81 Budzinski, Oliver; Beigi, Maryam H. A.: Competition Policy Agendas for Industrializing Countries, Mai 2013. 
Nr. 82 Budzinski, Oliver; Müller, Anika: Finanzregulierung und internationale Wettbewerbsfähigkeit: der Fall Deutsche Bundesliga, Mai 2013.

Nr. 83 Doose, Anna Maria: Methods for Calculating Cartel Damages: A Survey, Dezember 2013.

Nr. 84 Pawlowski, Tim; Budzinski, Oliver: Competitive Balance and Attention Level Effects: Theore-tical Considerations and Preliminary Evidence, März 2014.

Nr. 85 Budzinski, Oliver: The Competition Economics of Financial Fair Play, März 2014.

Nr. 86 Budzinski, Oliver; Szymanski, Stefan: Are Restrictions of Competition by Sports Associations Horizontal or Vertical in Nature?, März, 2014.

Nr. 87 Budzinski, Oliver: Lead Jurisdiction Concepts Towards Rationalizing Multiple Competition Policy Enforcement Procedures, Juni 2014.

Nr. 88 Budzinski, Oliver: Bemerkungen zur ökonomischen Analyse von Sicherheit, August 2014.

Nr. 89 Budzinski, Oliver; Pawlowski, Tim: The Behavioural Economics of Competitive Balance: Implications for League Policy and Championship Management, September 2014.

Nr. 90 Grebel, Thomas; Stuetzer, Michael: Assessment of the Environmental Performance of European Countries over Time: Addressing the Role of Carbon

Nr. 91 Emam, Sherief; Grebel, Thomas: Rising Energy Prices and Advances in Renewable Energy Technologies, July 2014. 